\title{
The Impact of Welfare Reform on
}

\section{Leaver Characteristics, Employment and Recidivism}

\author{
William J. Carrington \\ Welch Consulting \\ 7984 Old Georgetown Rd., Suite 7C \\ Bethesda, MD 26814 \\ Peter R. Mueser \\ Department of Economics \\ University of Missouri-Columbia \\ Columbia, MO 65211 \\ mueserp@missouri.edu \\ Kenneth R. Troske \\ Department of Economics \\ University of Missouri-Columbia \\ Columbia, MO 65211 \\ troskek@missouri.edu
}

June 2002

We would like to thank Tricia Gladden, Robert Hutchens and Lucie Schmidt and seminar participants at Clemson University for helpful comments. Mueser and Troske would like to thank the Employment Policies Institute for financial support. June Cheng provided excellent research assistance. All errors are our own. 


\title{
The Impact of Welfare Reform on \\ Leaver Characteristics, Employment and Recidivism
}

\begin{abstract}
Welfare reform has transformed the U.S. cash assistance program for single parents and their children. Although there remains substantial uncertainty about the importance of reform in producing the subsequent decline in the welfare caseload, even less is known about its impact on the experiences and well being of former welfare recipients. The analysis here focuses on the characteristics and employment of welfare recipients in the state of Missouri over the period 1990-1999. We find that there has been little change in the observable characteristics of those entering, on, or leaving welfare, but there has been a dramatic growth in the importance of employment for all these groups. We also examine the dynamics of employment and welfare recidivism comparing cohorts of leavers prior to and after welfare reform. We find that after welfare reform leavers are much more likely to be working, have higher total earnings, work for employers with similar characteristics, and are less likely to return to welfare. These results suggest that welfare reform has not materially harmed welfare recipients.
\end{abstract}




\section{Introduction}

Welfare reform legislation at both the state and national levels over the past decade has transformed the U.S. cash assistance program for single parents and their children. The first goal of reform was to reduce the welfare caseload. Caseloads have now declined in every state from peaks in the mid-1990s, with the national caseload declining by more than one half. ${ }^{1}$ The second goal was to improve the long-run well being of current and former welfare recipients by helping them achieve self-sufficiency through employment. Previous research has shown that postreform welfare leavers have relatively low levels of job skills and are working in jobs with low wages, few benefits, and little security. On the other hand, it is well-known that welfare leavers have always had relatively few job skills and have tended to work in low paying jobs. Therefore, the impact that welfare reform had on the well being of recipients remains an open question.

This paper explores this question by examining the dynamics of welfare participation and employment in the state of Missouri over the period 1990-1999. Federal reform replaced Aid to Families with Dependent Children (AFDC) with Temporary Assistance for Needy Families (TANF) in late 1996. But like most other states, Missouri had instituted substantial reform by that time with the most important changes occurring the implementation of state-level reforms in 1995. While the structure of welfare reform differed substantially across states, those in

\footnotetext{
${ }^{1}$ There remains some uncertainty about the importance of reform in producing this decline. Recent reviews of the literature on the impacts of welfare reform and the economy on caseloads are provided in Bell (2001) and Blank (2002); a broader survey of the literature on the factors influencing welfare caseloads is provided in Mayer (2000). Meyer and Rosenbaum (2001) provide an analysis focusing on the role of the federal Earned Income Tax Credit. Perhaps the most influential single study is the Council of Economic Advisors (1999) report, and the best collection of studies is Danziger (1999).
} 
Missouri are as representative as any (Fender, McKernan and Bernstein, 2001). Missouri's welfare caseload displays a pattern very similar to that for the U.S. as a whole, reaching a peak in 1994, with a decline to approximately half the peak level by the end of the decade. These facts suggest that lessons learned from the Missouri welfare experience may have broader implications.

We first examine changes in the demographic and family characteristics of welfare recipients, and those moving onto and off of welfare over the period 1990:3 to 1999:3, spanning the period of active welfare reform. Aside from providing an initial indication of the impacts of welfare reforms, these analyses suggest the degree to which results may be influenced by changes in the characteristics of welfare recipients due to reform (Hoynes, 2001). We also examine changes in the welfare and employment history of recipients moving onto and off of welfare over the 1990s.

We then consider the experiences of two cohorts of welfare leavers, those leaving welfare in fiscal year 1993 (July 1992-June 1993), and those leaving welfare in fiscal year 1997 (July 1996-June 1997). The first period identifies welfare leavers prior to welfare reform. At that point, Missouri's welfare caseload was still increasing, and the regulations governing welfare were essentially those of the standard AFDC program, which had changed relatively little since the early 1980s. The second period occurs after substantial policy change. Our ability to compare recipients prior to reform with recipients after reform is one of the main strengths of our analysis. Using these data we examine the dynamics of employment and welfare recidivism for welfare leavers as well as changes in the characteristics of welfare leavers' employers. This latter 
analysis is important because previous research has shown that employer characteristics, such as size, industry and wages, are correlated with an employee's wages, benefits, wage growth, and employment stability (Krueger and Summers, 1988; Brown, Hamilton and Medoff, 1990; Davis and Haltiwanger, 1992; Troske, 1999). A comparison of the detailed patterns for these cohorts allows us to directly consider changes occurring over the period of welfare reform.

The remainder of the paper is organized as follows. The next section briefly reviews the literature on welfare and welfare reform. We then review the history of Missouri welfare reform and provide a brief overview of the Missouri economy. Section V describes our data. Section VI describes how the welfare caseload has changed between 1990 and 1999 by examining employment and demographic characteristics for those entering and leaving welfare. Section VII examines changes in the welfare and employment history of those in the welfare system. Section VIII contains the results from our analysis of the two cohorts of welfare leavers. Finally, we summarize our results and present conclusions in section IX.

\section{Previous Research Examining Welfare, Employment, and the Impact of Reform}

Concern with the work activities of welfare recipients goes back to at least the 1960s, when implementation of the federal Work INcentive (WIN) program required states to assure that recipients had access to job search services. Corresponding with this popular concern was a body of research examining the work disincentive effects of AFDC. Although early work suggested that the labor market was of secondary importance in explaining flows onto and off of welfare (Moffitt, 1992), by the early 1990s, new research found that 40-70 percent of exits from 
welfare in the mid-1980s were associated with employment (Blank, 1989; Harris, 1993; Blank and Ruggles, 1996). Consistent with the view that both the labor market and the marriage market play a role, analyses examining the determinants of welfare exits showed that measures indicating opportunities in both the labor and marriage markets were associated with welfare exits (Fitzgerald, 1991; Hoynes, 1997; Ribar, 2000).

Previous research also found that welfare recidivism was related to labor market conditions. Among welfare leavers with employment, the kind of job held plays an important role in determining whether the individual returns to welfare, with those in higher paying industries less likely to return (Lane and Stevens, 1995, 2001; Bartik, 1997; but see also Harris, 1996).

Research based on data from AFDC prior to reform also shows that welfare experiences do not preclude later labor market success. When individuals observed receiving AFDC at a given point in time are followed for several years, labor force participation and earnings increase (O’Neill and O’Neill, 1997) and some studies suggest that wages actually approach those of similar individuals who did not participate in AFDC (Moffitt and Rangarajan, 1989). Insofar as welfare recipients continue to fare less well than others, this appears to be the result of less stable employment (Gladden and Taber, 2000; Loeb and Corcoran, 2000).

Of course, these findings are based on examining AFDC recipients, who could continue to receive benefits indefinitely. In contrast, recipients under TANF face limits on the number of years they can receive benefits and are, with a few exceptions, required to work or participate in work-related activities in order to remain eligible for benefits. Given these changes, much 
interest has focused on the employment of recipients and reform's impact on welfare exits, and on the difficulties that former recipients have obtaining stable employment to provide earnings self-sufficiency.

Reforms have been associated with substantial increases in the levels of employment for recipients (Department of Health and Human Services, 2000). We know that those who leave welfare are likely to be working, but that their earnings are often very low and that many of them are suffering substantial hardship (Tweedie, et al. 1999; Brauner and Loprest, 1998; Parrott, 1998). In contrast to expectations, it does not appear that reforms have caused welfare caseloads to become more disadvantaged (Moffitt and Stevens, 2001), although since the implementation of TANF the proportion nonwhite has increased substantially (Zedlewskie and Anderson, 2001). Following reforms, employment continues to play an important role in welfare exits, but existing studies provide little basis for examining changes in the dynamics of welfare use and employment occurring with reform. This is because most studies focus on recipients after reform as opposed to comparing the behavior of recipients before and after reform. Two studies that do make this comparison are Loprest (2001) and Cancian, et al. (2002). Loprest (2001) uses a national sample to compare the experience of individuals leaving welfare in 1995-1997 with those leaving in 1997-1999. She finds that the levels of employment and earnings are, if anything, higher in the more recent period. Unfortunately, this does not provide a clear picture of the impact of reforms since most states had already enacted major reforms to their welfare system prior to or during the 1995-1997 period. Cancian, et al. (2002) use administrative data from Wisconsin and compare individuals leaving welfare in September 1995 with those leaving 
welfare in September 1997. Similar to Loprest, Cancian, et al. find that the rate of employment is higher in the later cohort, but, in contrast to Loprest, they find that earnings are lower. However, Cancian et al. are also unable to make a clear comparison between leavers prior to welfare reform and after welfare reform because Wisconsin had substantially reformed its welfare system prior to 1995 . As we discuss in more detail below, one of the main advantages of our study relative to Loprest (2001) and Cancian et al. (2002) is that, given the time-series length of our data and the timing of welfare reform in Missouri, we are able to compare individuals who left welfare well before any changes in the system occurred with those who left welfare well after reforms were implemented.

\section{Welfare Reform in Missouri}

Reflecting stability in the federal AFDC program, Missouri's welfare system was essentially unchanged until the passage of major state welfare reform legislation in 1994, which was implemented in 1995 with federal approval of a statewide waiver. The new legislation required each nonexempt recipient to enter into a "self-sufficiency pact" that spelled out a plan for obtaining self-supporting employment within two years. It also raised allowable asset levels, increased efforts to establish paternity, made grandparents responsible for child support in some cases, required minor parents to live with their parents, established a wage supplementation program, and instituted other program changes. It also provided for sanctions, i.e., a reduction in the case grant amount for recipients failing to meet training, work, or other requirements. Despite the apparent scope of the legislation, in the short run it provided only moderate changes 
in the rules faced by a typical recipient. In part it codified changes already under way, and it enabled a gradual reform process to continue.

Federal welfare reform replaced AFDC with Temporary Assistance for Needy Families (TANF) at the end of 1996, but associated policy changes in Missouri were relatively small, since state reform had already occurred, and no state legislation was passed at that time. One of the important changes in 1996 was the imposition of a five-year lifetime limit on welfare receipt. In addition, certain features of Missouri's welfare program, such as educational activities requiring lengthy participation, were eliminated or reduced because they were no longer acceptable under federal law. Exemptions from work requirements were also tightened, TANF requiring that a child be under age 1 for an exemption, in contrast to age 3 under prior rules.

Between 1993 and 1998, recipients faced increased restraints and growing pressure to participate in training and employment. An indication of the changes can be obtained by considering the likelihood that a recipient would face sanctions for violations of the rules. Since Missouri did not impose "whole case" sanctions (termination of all payments), sanctioned cases could continue to receive benefits at a reduced level for extended periods. Prior to 1994, in keeping with federal AFDC regulations, essentially no sanctions were applied. By the end of 1995 , the number had increased to about 1 percent of the caseload, growing steadily to well over 10 percent in 1998.

In addition to the program changes enacted, there were important and possibly significant changes in the way caseworkers were trained and rewarded during the 1990s. Through the early 1990s, caseworkers were evaluated for accuracy in processing applicants and assuring that they 
were placed on the welfare rolls promptly. A variety of training programs for caseworkers have attempted to refocus caseworkers' efforts on getting recipients into jobs and off of welfare. The legislative activity of the 1990s appears to have placed particular emphasis on the potentially temporary nature of welfare payments, and instructions to caseworkers require that this be emphasized to recipients. Informal reports suggest that recipients are more willing to move off of welfare, even if it may be temporary, in order to "bank" their five years of welfare eligibility. One result of the devolution of welfare from a federal program to a state program is that many states adopted slightly different reforms. A recent paper by Fender, McKernan and Bernstein (2001) tries to characterize welfare reform in each state. Data in this paper shows that welfare reform in Missouri was fairly typical. In particular, Missouri welfare recipients faced financial incentives to work and a welfare bureaucracy that was motivated to move recipients towards self-sufficiency. Thus, an examination of Missouri welfare recipients before and after welfare reform may tell us much about the broader impact of reform.

Like most states, Missouri does not have a state earned income tax credit. However, dramatic increases in the federal EITC, occurring in over the period 1994-1996, must be considered along with state welfare reforms as an important policy change influencing recipient behavior. 


\section{The Missouri Economy in Context}

Extrapolating from the Missouri experience requires some understanding of how the economic environment faced by Missouri welfare recipients compared with that of welfare recipients in the rest of the U.S. economy. This section places the Missouri economic experience of the 1990s in the context of the broader U.S. experience over that same period.

Table 1 presents summary data on the economies of both Missouri and the United States as a whole, for both 1991, which was before welfare reform began in Missouri, and 1999, which was after the important reforms had been in place for several years. The table shows that the fraction of employment accounted for by broad industries in 1991 was quite similar for Missouri and the U.S. as a whole. Missouri and the U.S. as a whole moved away from manufacturing (particularly durable manufacturing) and towards services and construction.

Table 1 also compares the racial compositions of the populations of Missouri and the U.S. as a whole. While Missouri has a close-to-average share of African-Americans in its population, other minorities are under represented. In 1999, Asians account for only about 1 percent of the Missouri population, compared with 4 percent for the country as a whole, and Hispanics account for less than 2 percent of the Missouri population, compared with over 11 percent for the country as a whole. These patterns are largely driven by recent patterns of immigration, which has tended to settle on the coasts instead of the Midwest. These general demographic patterns carry over to the welfare population, where the share of Asians and, particularly, Hispanics in the Missouri welfare population is well below the national average. 
The remainder of Table 1 compares the income and earnings of Missourians with those of the U.S. population as a whole. The panels indicate that average personal and household income of Missouri is generally slightly below that of the United States as a whole. ${ }^{2}$ These same patterns are observed in the patterns for average weekly earnings and average hourly wage. Finally, it is worth noting that Missouri has two large urban areas, Kansas City and St. Louis, although the state is somewhat less urbanized than the nation as a whole (69 percent urban in Missouri vs. 75 percent urban in the U.S. as a whole, in 1990). In sum, Missouri is a fairly representative state from most demographic and economic perspectives. The major differences between Missouri and the rest of the U.S. over this period are that there are fewer non-black minorities in Missouri than elsewhere and that Missouri is somewhat less urban.

While Table 1 provides broad insight into the differences between Missouri and the rest of the U.S., it provides little insight to the precise timing of short-run labor market developments. Such temporary fluctuations are of obvious potential importance when interpreting the patterns of success and failure in Missouri welfare reform. For this reason, Figures 1-3 report time-series summaries of how the Missouri labor market evolved in comparison to the broader U.S. labor market. The charts are based on microdata drawn from the March surveys of the 1991-2000 Current Population Survey, which measure labor market performance for the preceding year. In these graph we will focus on women since this is the group primarily affected by welfare reform. ${ }^{3}$

\footnotetext{
2 The 1998/99 figures that show dramatic growth in household income for Missouri appear to be a result of sampling error.

${ }^{3}$ One possibility is that welfare reform affected the female labor market itself. Therefore, differences in Figures 1-3 between the U.S. and Missouri could be due to differences in the timing of welfare reform. To examine this possibility we have created similar figures using data
} 
Figure 1 reports the evolution of the unemployment rate for women between the ages of 20 and 60 for both the U.S. and Missouri. The chart shows that while the Missouri unemployment series fluctuates more, the general patterns of rise and fall in Missouri were quite similar to those of the U.S. as a whole. Figure 2 reports the median hourly wage for women between the ages of 20 and 60 over the same period. The chart shows that median female wages in Missouri and the U.S. as a whole have moved in quite a similar fashion over this period. Welfare recipients, of course, may have labor market skills that are less comparable with the median female than they are with the lower tail of the female wage distribution. For this reason, Figure 3 plots the 25 th percentile of the hourly wage distribution for Missouri and the U.S. as a whole. The chart shows that the lower tail of the two distributions also moved in a similar fashion.

In sum, the evidence presented here suggests that the economies of Missouri and the rest of the United States both started and ended the 1990s in a similar position, and that the labor markets evolved in a similar fashion over this period. This suggests that the people affected by Missouri welfare reform in the 1990s were operating in an economic environment that was fairly representative of general economic conditions in the U.S. over this period. This is no guarantee that one can extrapolate from the Missouri experience, as the Missouri economy could be idiosyncratic along dimensions not measured here. Nevertheless, the limited evidence presented here as well as our own study of the issue suggests that Missouri is broadly representative.

\footnotetext{
for men instead of women with nearly identical results.
} 


\section{Data}

Our data on AFDC/TANF recipients come from administrative records maintained by the state of Missouri in the form of monthly files from July 1990 through September 1999. Our analyses focus on female payees in the AFDC-Basic program or its TANF successor who are at least 18 and at most 56 years of age. "Child only" cases are omitted, since the payee in such cases receives a grant on behalf of children but does not have formal responsibility for them and is therefore exempt from the work or training requirements that parents face. Welfare recipients with only in-kind payments are also excluded.

Since two-parent families receiving payments under the AFDC-UP program are omitted, the unit of our analysis is a single mother with children who receives cash welfare payments, or equivalently, a welfare case headed by such an individual. We have combined the monthly data into quarters, so that recipients are those who receive payments and met our other selection criteria in any month during a quarter. A recipient in a given quarter is defined as a welfare arrival or entry if she was not a recipient in the prior quarter; and she is defined as a exit or leaver if she is not a recipient in the subsequent quarter. Since our information on program participation is limited to Missouri, an individual who had received welfare payments in another state would be considered as a new arrival, and welfare in the previous state would not be measured. ${ }^{5}$

\footnotetext{
${ }^{4} \mathrm{We}$ limit the analysis to individuals who are at most 56 years old because we are focusing on subsequent employment and older workers may not face the same incentives to work. As a practical matter, given that most recipients are fairly young, this restriction has very little effect on our results.

${ }^{5}$ Payees under 18 years of age are not included in our analysis, and so such cases would be coded
} 
Employment and earnings information derives from "wage record" data maintained by the states of Missouri and Kansas in support of their unemployment insurance systems. ${ }^{6}$ For every individual employed in a covered job, the files indicate total quarterly earnings, along with selected employer information. While the vast majority of the employment for Missouri residents is included in these files, self-employment, illegal or informal employment, certain federal employment, and employment outside Missouri and Kansas are not included. ${ }^{7}$ We match recipient records from the welfare data to the wage record data using Social Security Number. If we do not find a record for an individual in a given quarter in the wage record data, we consider the individual to be not employed.

Other work using welfare data from Missouri suggests that the basic demographic structure of Missouri's caseload, levels of employment for welfare recipients, and changes in these patterns over the 1990s is similar to those in other states. Mueser and King (2001) compare welfare patterns for Kansas City, Missouri with those in five major metropolitan areas, representing the midwestern and southern U.S. Heinrich, Mueser, and Troske (2002) provide comparisons between state caseloads for Missouri and North Carolina.

as a welfare entry on reaching 18 . Since special rules apply to payees under 18 , we believe it is most useful to view them as entering a new program at that point.

${ }^{6}$ See Hotz and Scholz (2000) for a discussion of the advantages and limitation of these data for studying the employment patterns of welfare recipients.

${ }^{7}$ Inclusion of Kansas wage record data is of substantial value, since approximately 15 percent of the jobs held by welfare recipients in Jackson County, Missouri (the central county of Kansas City) were in Kansas. In contrast, including Illinois employment would not influence our results. In St. Louis City, less than 2 percent of the jobs held by welfare recipients were in Illinois. 


\section{Caseload Dynamics}

\section{Patterns of Welfare Entry and Exit}

This paper examines the post-welfare experience of welfare leavers both before and after welfare reform. Any differences in outcomes between the two groups can be due to differences in incentives provided by the two systems. However, differences between the two groups may also be due to time-series variation in the demographic and economic composition of welfare exiters. Given the steady improvement in economic conditions in Missouri and the broader U.S. economy, this latter hypothesis merits serious consideration. To get a handle on this issue, this section examines time-series changes in the characteristics of both welfare leavers and the broader welfare caseload. The hope is that this information will allow for more educated interpretations of our later findings.

Did welfare reform alter the composition of the welfare population in Missouri? Alternatively, did welfare reform affect who entered the welfare system? Some observers have suggested that under welfare reform the relatively able would be the first to move off of welfare, leaving behind those least prepared to enter the labor market. Figure 4 begins to address these questions by tracking the welfare caseload and flows onto and off of welfare for Missouri for each quarter from 1990:3 to 1999:3. Since there is appreciable seasonal variation in arrivals and departures, as well a variation due to small numbers, Figure 4 presents these statistics using a four-quarter moving average. ${ }^{8}$ The figure shows that the caseload grew steadily in the first half

\footnotetext{
${ }^{8}$ The quarter indicated in the figures is the fourth quarter of the year to which the average applies. The paper's appendix includes figures providing original quarterly data corresponding to all figures in the text.
} 
of the 1990 s and that it reached a peak of just over 74,500 in the third quarter of 1994 . In 1995 , however, the caseload began a steady and dramatic decline, leading to a caseload of fewer than 40,000 by the end of 1999 .

The number of individuals entering welfare each quarter averages over 8000 in each year through 1994, after which it declines steadily to around 6000. The average quarterly flow off of welfare increases from about 7000 to a peak of over 9000 in 1997 and then declines to below 8000. This decline is due to a decline in the caseload, which is of course the population at risk, rather than to a decline in the exit rate among the caseload. Figure 5 makes this point more clearly with a graph of the 4-quarter moving average of the quarterly exit rate. The exit rate remains close to 11 percent through 1994 , but it increases steadily to nearly 19 percent by the end of our period. The changes seen in the welfare case load in Missouri over the 1990s, as well as the changes in the number of arrivals, leavers and the exit rate, closely resemble changes seen in the nation as a whole and in a number of other states (Gittleman, 2000; Mueser and King, 2001). This provides further evidence that the changes in welfare in Missouri were fairly typical.

\section{Changes in the Characteristics of the Caseload and Flows}

Did welfare reform alter the composition of the welfare population? Figure 6 provides information on the characteristics of those receiving welfare and on those entering and exiting welfare. Panel A shows that the age of the youngest child among welfare recipients increases slightly, averaging just over 4.8 in the early 1990s, reaching 5.1 in 1996, and declining to around 
4.9 in the last year. As might be expected, those entering welfare have younger children, while those exiting have older children. Over this period, the gap narrowed somewhat.

Panel B of Figure 6 shows that the average years of schooling of the welfare caseload increased to the late 1990s, then declined to its initial level, although the increase and decrease is less than 0.1 year. Perhaps more noteworthy is that both arrivals and leavers have more schooling than the caseload as a whole, as educated recipients are more likely to be short term recipients. The educational level for both arrivals and departures follows that of the caseload, however, as average schooling first increases and then decreases.

Panel C of Figure 6 shows that there were more substantial changes in the racial composition of the welfare caseload over this period. While 47 percent of the caseload in 1994 was nonwhite, this had increased to over 56 percent by 1999. Note also that both flows have fewer nonwhites than the caseload as a whole, which merely reflects the fact that whites have shorter spells on welfare. During this period, the racial composition of arrivals and exits moved together, with the proportion nonwhite in both increasing.

In order to examine the reasons behind the increase in the proportion nonwhite in more detail, Appendix Figure A-4 presents the number of arrivals and departures separately for whites and nonwhite, while Appendix Figure A-5 presents the exit rate separately for the two groups. Examining these two figures it is easy to see why the proportion nonwhite has grown. While the number of whites coming onto welfare has declined by nearly 40 percent since 1994, for nonwhites the decline has been less than 10 percent. The trends in exit rates, however, partly compensate for this difference. Quarterly exit rates for whites increase from about 16 percent per 
quarter during 1994 to 20 percent by the end of our period, a change that would produce a decline of about 20 percent in the white caseload over the long run. Nonwhite exit rates are lower throughout the period, but their increase is much greater. In 1994, nonwhite exit rates are about 8 percent, increasing to 14 percent by the end of the 1990s, which, in the absence of any other changes, would produce a decline of more than 40 percent in the nonwhite caseload. Perhaps the most important observation is that although the overall decline in the white caseload is greater, for both groups the decline is large, with changes in the in the number of arrivals and in the exit rate playing a role.

Panel D of Figure 6 shows that the age of the payees increased by about 0.4 years through 1997 and then decreased slightly in the following two years. Of course, as might be anticipated, those entering welfare are appreciably younger, by approximately two years, than the caseload as a whole. Those exiting welfare are only slightly older than the caseload.

With the exception of race, changes in the demographic characteristics of welfare recipients in Missouri over the 1990s are small. Perhaps of equal interest, the characteristics of those entering and exiting followed very similar patterns to that of the caseload. There is some evidence that the December 1996 implementation of TANF had an influence on the dynamics, given that for several graphs inflection points occur around that time. However, it is the stability rather than the changes that are most notable. The relative stability in mean education for the caseload, for arrivals, and for departures suggests that reform did not have disproportionate effects on more able recipients. More generally, the stability suggests that the selection effects of 
welfare reform are not so strong as to vitiate comparisons over time in the experiences of welfare recipients.

\section{Prior Welfare Experience and Employment for Welfare Recipients}

Figure 7 provides information on the prior welfare and employment experience for the welfare population. Panel A shows that there has been very little change in the extent to which welfare recipients have prior welfare experience. In the two prior years, the average recipient had received payments during approximately six quarters. Those exiting welfare had spent slightly

more than four quarters receiving welfare. We observe an increase in leavers' welfare experience through 1997, presumably reflecting efforts on the part of welfare reformers to remove long-term recipients from the rolls. Perhaps the only important surprise is a substantial trend in the prior welfare experience of those entering welfare. Whereas in the early $1990 \mathrm{~s}$, the average welfare arrival had received welfare during approximately one quarter in the prior year, this had increased by about 50 percent by the end of the 1990s.

Panel B shows that welfare payments gradually became less important as a source of income for welfare recipients. Among recipients, the fraction of income from welfare declined from close to 70 percent to about 55 percent. There was a more modest decline among those leaving welfare. In contrast, consistent with the observation that entries were more likely to have welfare experience, there was a modest increase in reliance on welfare among new recipients.

Perhaps most striking is the increase in the extent of prior earnings for welfare recipients (Panel C). Among welfare recipients the proportion of the prior eight quarters with positive 
earnings rose from slightly less that 25 percent to almost 45 percent. An increase is also observed for those leaving welfare and those entering. We also see that the leavers become more similar to the overall caseload during the 1990s. The results in Figure 7 show that welfare reform is associated with both a large increase in the percent of welfare recipients who are working in a given quarter and with a fairly substantial decline in the fraction of a welfare recipient's income coming from welfare.

\section{Comparing Two Leaver Cohorts}

The Impact of Missouri Reforms on Welfare Leavers: Employment and Recidivism

To consider how the experiences of welfare leavers have changed over time, we focus here on two cohorts of leavers: those leaving welfare between July 1992 and June 1993, and those leaving welfare between July 1996 and June 1997. The first period predates major welfare reform in the state, and, with relatively few exceptions, the rules correspond to those of the AFDC system that had been largely unchanged since the early 1980s. The caseload was also growing at this point. The second period is nearly two years after implementation of the state's major welfare reform, and corresponds to implementation of the federal TANF program in the state. Caseloads are declining at that point and are about 10 percent below their peak level in 1994.

The top panel of Figure 8 shows the proportion of leavers who return to welfare during the next eight quarters. The solid line indicates the earlier period and the dotted line the later 
period. ${ }^{9}$ A leaver is defined by receipt of welfare in a particular quarter and no welfare in the following quarter, so this measure is zero for the first quarter after the quarter of exit by construction. The lines show that in the second quarter about 10 percent of leavers are again receiving welfare and that this proportion increases for both cohorts up through the fourth quarter.

Differences between the two cohorts are striking. Among leavers in the earlier period, approximately 23 percent were receiving welfare by the eighth quarter after leaving, while the comparable figure is only 15 percent for the later period. We also see that for the later period, there is a pronounced peak in quarter 4 , where 17 percent of leavers are again receiving welfare. The decline in welfare receipt over the next four quarters reflects the fact that some of those who return to welfare leave again, outnumbering the flow of those returning. ${ }^{10}$

Panel B shows the employment rate in the following eight quarters for the two cohorts. This figure shows that there is a dramatic increase in the probability of being employed for the later cohort of leavers for all eight quarters. Among the early cohort, four quarters after leaving

\footnotetext{
${ }^{9}$ The statistics in Figure 8 aggregate the experiences of individuals leaving welfare in any of the specified quarters. For example, those who leave welfare in 1992:3 are followed for 1992:41994:3, while those who leave welfare in 1992:4 are followed for 1993:1-1994:4. This means that an individual who left welfare, returned, and then left again within 1992:3-1993:2 would be counted as a leaver twice in this analysis. (The number of such cases is small.) We were concerned about possible differences in the experiences of individuals leaving welfare in different quarters within each two-year period, and so we calculated statistics in both panels of Figure 8 separately for each quarter. Although small differences exist, these are dwarfed by the differences between the two cohorts. Figure A-7 presents these disaggregated results.

${ }^{10}$ We have examined the probability of returning for leavers over the entire 1990s and see very similar patters-leavers in the later half of the decade are much less likely to return to welfare within eight quarters than leavers in the early part of the decade.
} 
welfare only 50 percent are employed, while 60 percent of the later cohort is employed four quarters after leaving welfare. ${ }^{11}$

It is clear that after reform welfare leavers are much more likely to be working. If this increase in employment is primarily the result of stringent work requirements imposed, we might expect that the increased employment rate would be accompanied by a decline in earnings. To examine this possibility, Figure 9 compares earnings over time for our two cohorts of welfare leavers. ${ }^{12}$ The top panel presents the average earnings for all leavers, including those with no earnings. Panel B graphs average earnings for those with jobs. ${ }^{13}$ Average earnings of the later cohort are well above the average earnings of the earlier cohort. Comparing the two panels shows that this is not simply due to a larger percentage of leavers being employed in the later cohort. Average earnings are higher for the later cohort even focusing exclusively on employed leavers. Therefore, measured purely in material terms, it does not appear that welfare reform has pushed ever more marginal individuals into the labor market. ${ }^{14}$

\footnotetext{
${ }^{11}$ We have examined the rate of employment for welfare recipients as well as those coming onto and those leaving welfare for the 1990s. In these data we also see that employment plays a much more important role in the welfare dynamic after reform.

${ }^{12}$ Earnings are measured in 1999 quarter 2 dollars.

${ }^{13}$ Earnings vary substantially from quarter to quarter, in large part due to seasonal effects. Since the cohorts graphed in Figure 9 combine leavers in four quarters, they smooth these effects. Figure A-8 presents results for leavers in each of the four quarters in each cohort.

${ }^{14}$ This is not to say that individuals leaving welfare after reform have high earnings. Rather, their earnings are higher than the earnings of individuals who left welfare prior to reform. And while the level of earnings are very low, we should note that they are at the level where, when combined with the Earned Income Tax Credit, they would provide earnings that could exceed the poverty level. In addition, Medicaid eligibility would continue for those leaving welfare for at least a year.
} 
Table 2 provides information on the kinds of jobs welfare recipients obtain when they leave welfare and how their jobs changed over the following two years. In Columns (1) and (2) information is provided on employed recipients from the 1992-1993 cohort while information on the 1996-1997 cohort appears in Columns (3) and (4). For each cohort, job characteristics are provided for the first quarter after leaving welfare (Columns (1) and (3)) and for the eighth quarter after leaving welfare (Columns (2) and (4)). By definition, none of those identified in the first quarter after leaving welfare are welfare recipients at that time, but the measures based on the eighth quarter after leaving welfare include individuals who returned to welfare. All statistics in the table focus on the characteristics of employers of welfare recipients, so individuals who are not employed are omitted. ${ }^{15}$

Panel A shows that welfare leavers are very likely to have jobs in retail trade and service firms, and that this proportion grew modestly between our cohorts. Looking at the industry detail, we see that nearly 14 percent of leavers are working in eating and drinking places in the quarter after leaving welfare, but that this proportion declined slightly between periods. The proportion of welfare leavers working in manufacturing firms declined by nearly a third in the five-year period. The most dramatic increase among detailed industries is in help supply services ("temp help"), which increased from 5.3 percent of leavers to 8.2 percent in the first quarter after leaving. ${ }^{16}$

\footnotetext{
${ }^{15}$ In Tables 2 and 3, for workers with more than one job in a quarter, we provide information on the employer paying the greatest earnings.

${ }^{16}$ This growth in the employment of welfare leavers in the temporary help industry reflects both the overall growth in employment in this industry (Autor, forthcoming) and an increase in the relative reliance on such jobs for welfare recipients (Heinrich, Mueser and Troske, 2002).
} 
If we compare the first quarter after leaving welfare with the eighth quarter, we see that the progression is quite similar for the two cohorts. There is little evidence that leavers in the recent period are more likely to remain in unstable or marginal jobs. For example, in both periods, leavers move out of jobs in restaurants and nursing homes, and into jobs in manufacturing, transportation and communications. One modest shift in the pattern occurs for temporary help, which shows an increase between the first and the eighth quarter for those in the earlier cohort but a decrease for the later cohort.

Panel B in Table 2 compares the size of firms hiring welfare leavers. Here we see that among leavers in the more recent cohort, appreciably more are working for the largest firms. Whereas in the earlier period, workers tended to move into larger firms, in the recent period, the change is small.

Panel C shows that, initially, both cohorts of welfare leavers work for firms with very similar pay but that progression over the two years after leaving welfare is greater for the more recent group. Perhaps most notable, eight quarters after leaving welfare, nearly 30 percent of leavers in the 1992-1993 cohort worked for firms with wages averaging below $\$ 2000$ per quarter, whereas that number had declined to 25 percent for the 1996-1997 cohort. This again suggests that welfare reform is not pushing less qualified workers into the labor market. Finally, Panel D shows that welfare leavers are less likely than in the past to be working in a firm with a large share of welfare recipients. Welfare reform does not appear to have pushed leavers into positions with employers who specialize in hiring welfare recipients. 
Table 3 presents similar employment information for all workers in Missouri. Column (1) presents information for all workers in the fourth quarter of 1992, which is comparable to the employment information for the 1992-1993 cohort of welfare leavers in Table 2. Column (2) presents information from the fourth quarter of 1996, which is comparable to the employment information for the 1996-1997 cohort of welfare leavers.

Comparing Panel A in Table 3 with Panel A in Table 2 shows that former welfare recipients are much more likely to work in the retail trade and services sectors and less likely to work in all other sectors then the typical Missouri workers. Looking at the detailed industries we see that former welfare recipients are particularly over represented in eating and drinking places, hotels and motels, help supply services, and nursing homes.

Comparing the information in Panel B in the two tables we see that former welfare recipients are less likely to work in the smallest (1-19) and largest firms (over 1000). Panel C in the two tables shows that former welfare workers tend to work for low paying firms. Relative to the typical Missouri worker, former welfare recipients are over twice as likely to work for a firm that pays average quarterly earnings of less than $\$ 2000$ and are almost six times less likely to work for a firm that pays average quarterly earnings over $\$ 7500$. Finally, comparing the information in Panel D in the two tables shows that welfare recipients are much more likely to work in firms where over 10 percent of the workforce is receiving welfare.

The information in Tables 2 and 3 shows that former welfare recipients do tend to work in firms that pay low wages and employ a large number of welfare recipients and tend to work in industries with high turnover. However, information in these tables also shows that this was true 
both before and after welfare reform. None of the information in these two tables supports the hypothesis that welfare reform forced less skilled workers to begin working or forced recipients into more unstable jobs or into jobs with employers specializing in hiring welfare recipients.

\section{The Determinants of Recidivism}

As the conditions for departure from welfare shift, we might assume that returns to welfare would have a different structure. To examine this possibility we estimate the probability of returning to welfare within two years for our set of welfare leavers using a probit model controlling for demographic characteristics, past welfare and work experience, location, and the attributes of an individual's job in the quarter immediately after leaving welfare. ${ }^{17}$ Table 4 presents estimates of the marginal effects of the variables. The analysis is performed separately for our two cohorts of former welfare recipients. Specification (1) includes the standard demographic characteristics along with the time on welfare in the past two years and the time working in the last two years. Time on welfare is measured as the proportion of quarters in the eight quarters prior to leaving that the individual was receiving welfare, and time working is measured in an analogous manner.

Specification (2) controls for the economic conditions of the local labor market by including the unemployment rate for the county where an individual lives and for whether she lives in a suburban county or a large metropolitan county (the excluded group is individuals who

\footnotetext{
${ }^{17}$ We also performed analyses predicting the chance of returning to welfare within one year, but the results were substantively indistinguishable from the two-year analysis.
} 
live in a small metropolitan county or a rural county). ${ }^{18}$ The large metropolitan counties consist of the counties containing St. Louis city and the Missouri portion of Kansas City. Specification (3) controls for the quarterly earnings received by former recipients in the initial quarter after leaving welfare. We include six dummy variables representing seven different earnings categories. Zero earnings is the excluded category and contains individuals with no job in the initial quarter off of welfare. ${ }^{19}$ Specification (4) includes controls for the industry of a recipient's employer in the first quarter off of welfare along with controls for the size of the employer.

To see more clearly the relationship between individual characteristics and the probability of returning to welfare, and how this relationship changes after welfare reform, we use the results from Table 4 to predict the probability that an individual with various attributes returns to welfare within two years. The results from this exercise are presented in Table 5. To obtain our base-line prediction we use mean values of the control variables computed across both cohorts. The $\hat{\beta}$ vector is taken from the specifications in Table 4 . For example, the probability in Row (1) Column (1) is 0.361 . This probability is calculated using the $\hat{\beta}$ vector from specification (1) for the 1992-1993 cohort times the means of the control variables calculated over individuals in both the 1992-1993 and 1996-1997 cohorts. The means for all of the controls are given in Appendix Table 1.

\footnotetext{
${ }^{18}$ The unemployment rate for an individual's county is measured as the county-level quarterly unemployment rate averaged over the eight quarters immediately after an individual leaves welfare. County-level quarterly unemployment comes from the Bureau of Labor Statistics Employment and Earnings data.

${ }^{19}$ We have also estimated the model using a continuous earnings measure and a dummy variable for whether earnings were zero in a quarter and the results were similar.
} 
In the second row of Table 5 we report the estimated probability of returning to welfare for the average individual in a cohort. For this calculation we again use the $\hat{\beta}$ vector from Table 4 , but multiply it by the cohort specific means of the control variables. These cohort specific means are also reported in Appendix Table 1.

The primary result of Table 5 is that the predicted rate of recidivism is substantially lower for the later cohort. While this mirrors the results seen in Figure 8, Table 5 shows that we continue to see the large fall in the recidivism rate even after controlling for demographic characteristics, local labor market conditions, and the characteristics of a leaver's employer. Comparing the results in the first and second rows shows that both the estimated probability of returning to welfare, and the change in the estimated probability across the two cohorts, are similar when computed for the average individual in the pooled data, or for the cohort-specific average individual. This finding shows that the fall in the probability of returning to welfare is not tied to changes in the characteristics of individuals leaving welfare, changes in the strength of the economy, or changes in the characteristics of welfare leavers' employers.

Both the time on welfare and time working variables are correlated with the probability that an individual returns to welfare. As one might expect, those with greater welfare experience are more likely to return to welfare. We also see that people who worked more in the past are more likely to return to welfare in the future. One might expect the employment and welfare experience variables to be negatively correlated, so that including welfare experience would influence the coefficient of time working. However, re-estimating the model dropping the welfare experience variable has little effect on the coefficient of work experience. Comparing 
across cohorts shows that these variables play a slightly more important role in predicting return to welfare in the earlier cohort, but the differences are small.

One possible explanation for the observed impact of work experience is that welfare leavers with more extensive work histories are likely to leave welfare with low paying jobs and therefore are more likely to return to welfare. The estimates for specification (4) in Table 4 show that those who leave welfare with low paying jobs are more likely to return to welfare. In fact, those with low paying jobs are more likely to return to welfare than those with relatively high paying job and are more likely to return to welfare than those with no job. The coefficients on the earnings dummy variables in Table 4 show that it is not until an individual has earnings above $\$ 3000$ in a quarter that she is less likely to return to welfare than an individual who has no job in the initial quarter after leaving welfare. While it may seem odd that women with zero earnings are less likely to return to welfare than those with modest earnings, previous research has found that welfare-leavers with zero post-welfare earnings have typically changed their household circumstances (e.g., marriage) in ways that offer a more persistent means of support than do very low earnings jobs (Moffitt, 1992; Blank and Ruggles, 1994).

While the basic observation that having a low paying job is associated with return to welfare is confirmed, it is of interest that the relationship between the probability of returning to welfare and prior work history is reduced only slightly when controls for type of job are included. Even after we control for industry and firm size, those with more extensive prior work histories are more likely to return to welfare. What this means is that, controlling for current employment, an individual who has sought welfare despite consistent employment is less likely to obtain 
complete self-sufficiency than one with little work history. While the previous research suggests that those leaving welfare because of employment would be particularly likely to return, nothing in prior work suggests the kind of mechanism we observe here.

One obvious question about the structure of recidivism for the 1996-1997 cohort is how much of the lower recidivism rate is due to the strong economy. To capture the effect that differences in economic conditions have on the rate of welfare recidivism we included in our model measures of the average unemployment rate in an individual's county of residence during the two years following leaving. The results in Table 4 show that cross-county differences in unemployment rates do have a significant impact on the likelihood of returning to welfare, with a 1 percent increase in average unemployment causing between a 1 and 1.5 percent increase in the chance of return. However, including unemployment and other the county level controls in the regression has very little impact on the other coefficients. Furthermore, average differences in unemployment between cohorts are small, so changes in unemployment plays essentially no role in explaining the lower levels of welfare recidivism for the 1996-1997 cohort. $^{20}$

We have tried a number of alternative specifications to capture the possible effects differences in economic conditions have on the probability of returning to welfare. Similar to Hoynes (2000), we have tried using the employment-to-population ratio and the average earnings in a county to capture local labor market conditions. ${ }^{21}$ In addition, we have pooled our data

\footnotetext{
${ }^{20}$ The mean of this variable is 6 percent in the first period and 5 percent in the second, while the standard deviation is around 2.5 percent in both. Hence, there appears to be substantial variation in the unemployment rate in both periods.

${ }^{21}$ Employment and average earnings in a county come from the unemployment insurance data. County population data come from the U.S. Census Bureau.
} 
across the two cohorts and included county-level dummy variables along with either the county level unemployment rate variable or our alternative measures of labor market conditions. Regardless of how we specify the model our basic results remain the same; very little of the fall in the probability of returning to welfare is attributable to changes in economic conditions.

When we compare the estimated impacts of individual characteristics and economic conditions across the cohorts, we see that, during this period of dramatic change in the welfare laws, the basic structure of the relationship between these variables and the probability of returning to welfare is unchanged. Overall then, much of the decline in the probability of returning to welfare seems attributable to welfare reform and related policy changes.

\section{Summary and Conclusion}

We have five main findings in this paper. First, for the most part there has been very little change in the characteristics of welfare recipients or the characteristics of those entering and leaving welfare between 1990 and 1999, despite dramatic declines in the overall caseload. This suggests that welfare reform has not significantly changed the type of person receiving welfare, and analyses focusing on welfare participants will not be seriously biased by selection. Second, we find that there has been dramatic growth in the importance of employment for those in the welfare system. Not only are those leaving welfare more likely to be working than in the past but so are welfare recipients and those entering welfare. We also show that this growth in employment has lead to a decline among welfare recipients in the fraction of their overall income coming from welfare payments. Third, when we examine the earnings of welfare leavers who 
are working, we do not find any evidence that welfare reform has pushed less skilled workers into the labor market. The earnings of those leaving welfare after welfare reform are higher than the earnings of welfare leavers prior to welfare reform. Fourth, we find that the type of firms employing welfare leavers has not changed much after welfare reform. It does not appear that after welfare reform recipients are any more likely to work for employers paying low wages or in industries with unstable employment. Finally, we find that over the 1990s there has been a significant decline in the probability that a welfare leaver returns to welfare. We do not find that economic factors played an important role in causing this decline, so we attribute the decline to changes in the welfare system and related policy.

These results suggest that welfare reform has not led to increased hardship for those on welfare or those leaving welfare. Nor is it the case that welfare reform has pushed less skilled individuals into the labor market. While individuals who leave welfare in the late 1990s do earn low wages and tend to work in less stable jobs, this was true of welfare leavers in the early 1990s as well. If anything, welfare leavers after welfare reform appear somewhat better off than welfare leavers prior to welfare reforms: they are more likely to be working after leaving welfare, they earn higher wages, and they are much less likely to return to welfare than previously. Of course, other policy changes, most importantly growth in the federal EITC, may have influenced the labor market behavior of welfare leavers. Nonetheless, our results suggest that, in the face of these changes, welfare reform has not materially harmed welfare recipients. 


\section{References}

Autor, David H. "Outsourcing At Will: The Contribution of Unjust Dismissal Doctrine to the Growth of Employment Outsourcing." Journal of Labor Economics, forthcoming.

Bartik, Timothy J. "Short-Term Employment Persistence for Welfare Recipients: The 'Effects' of Wages, Industry, Occupation, and Firm Size.” Unpublished paper, W.E. Upjohn Institute, June, 1997.

Bell, Stephen H. "Why Are Caseloads Falling?" Urban Institute Discussion Paper 01-02, March, 2001.

Blank, Rebecca M. "Analyzing the Length of Welfare Spells.” Journal of Public Economics, August 1989, 39(3), pp. 245-73.

Blank, Rebecca M. "Evaluating Welfare Reform in the United States.” NBER Working Paper 8983, June 2002.

Blank, Rebecca M. and Ruggles, Patricia. "Short-Term Recidivism Among Public-Assistance Recipients." American Economic Review, May 1994 (Papers and Proceedings of the American Economic Association), 84(2), pp. 49-53.

Blank, Rebecca M. and Ruggles, Patricia. "When Do Women Use Aid to Families With Dependent Children and Food Stamps? The Dynamics of Eligibility Versus Participation.” Journal of Human Resources, Winter 1996, 31(1), pp. 57-89.

Brauner, Sarah and Loprest, Pamela. Where are they now? What states' studies of people who left welfare tell us. New Federalism: Issues and Options for States, no. A-32. Washington, D.C.: Urban Institute, 1998.

Brown, Charles, James Hamilton and James Medoff, Employers Large and Small Harvard University Press, Cambridge, MA, 1990.

Cancian, Maria; Haveman, Robert; Meyer, Daniel R. and Wolfe, Barbara. "Before and After TANF: The Economic Well-Being of Women Leaving Welfare." Institute for Research on Poverty Discussion Paper No. 1244-02, University of Wisconsin, February 2002.

Council of Economic Advisors. Technical report: The effects of welfare policy and the economic expansion on welfare caseloads: An update. Washington, D.C.: The White House, 1999. 
Danziger, Sheldon H., ed. Economic conditions and welfare reform. Kalamazoo, Michigan: W.E. Upjohn, 1999.

Davis, Steve J., and John Haltiwanger, "Gross Job Creation, Gross Job Destruction, and Employment Reallocation." Quarterly Journal of Economics, August 1992, 107(3), pp. 819-63.

Department of Health and Human Services. "U.S. Temporary Assistance for Needy Families (TANF) Program: Third Annual Report to Congress.” August 2000. (http://www.acf.dhhs.gov/programs/opre/annual3.pdf)

Fender, Lynne; McKernan, Singe-Mary and Bernstein, Jen. "Taming the Beast: Catagorizing Welfare Policies for Use in Research A Typology of Welfare Policies Affecting Recipient Job Entry.” Washington, D.C.: Urban Institute, November 2001.

Fitzgerald, John. "Welfare Durations and the Marriage Market: Evidence from the Survey of Income and Program Participation.” Journal of Human Resources, Summer 1991, 26(3), pp. 545-61.

Gittleman, Maury. "Declining Caseloads: What Do the Dynamics of Welfare Participation Reveal?" Unpublished paper, Bureau of Labor Statistics, 2000.

Gladden, Tricia and Taber, Christopher. "Wage Progression Among Less Skilled Workers," in David E. Card and Rebecca M. Blank, eds., Finding jobs: Work and welfare reform. New York: Russell Sage Foundation, 2000, pp. 160-92.

Harris, Kathleen Mullan. "Work and Welfare Among Single Mothers in Poverty." American Journal of Sociology, September 1993, 99(2), pp. 317-52.

Harris, Kathleen Mullan. "Life After Welfare: Women, Work, and Repeat Dependency." American Sociological Review, June 1996, 61(3), pp. 407-26.

Heinrich, Carolyn J.; Mueser, Peter R. and Troske, Kenneth R. "Welfare to Temporary Work: Implications for Labor Market Outcomes." Paper presented at meetings of the Society of Labor Economists, May 2002.

Hotz, V. Joseph, and John Karl Scholz. "Measuring Employment and Income for Low-Income Populations With Administrative and Survey Data." Unpublished paper, UCLA, June 2000. 
Hoynes, Hilary Williamson. "Work, Welfare, and Family Structure: What Have We Learned?" in Alan J. Auerback, ed., Fiscal policy: Lessions from economic research. Cambridge, Mass.: MIT Press, 1997, pp. 101-46.

Hoynes, Hilary Williamson. "Local Labor Markets and Welfare Spells: Do Demand Conditions Matter?" The Review of Economics and Statistics, August 2000, 82(3), pp. 351-398.

Hoynes, Hilary Williamson. Discussion of Pamela Loprest, "How Are Families Who Left Welfare Doing Over Time? A Comparison of Two Cohorts of Welfare Leavers." Economic Policy Review, September 2001, 7(2), pp. 21-22.

Krueger, Alan and Lawrence Summers, "Efficiency Wages and the Inter-Industry Wage Structure." Econometrica, March 1988, 56(2), pp. 259-293.

Lane, Julia and Stevens, David. "Family, Work and Welfare History: Work and Welfare Outcomes." American Economic Review, May 1995 (Papers and Proceedings of the American Economic Association), 85(2), pp. 266-70.

Lane, Julia and Stevens, David. "Welfare-To-Work Outcomes: The Role For the Employer." Southern Economic Journal, April 2001, 67(4), pp. 1010-21.

Loeb, Susanna and Corcoran, Mary. "Welfare, Work Experience, and Economic SelfSufficiency.” Unpublished, School of Education, Stanford University, 2000.

Loprest, Pamela. "How Are Families Who Left Welfare Doing Over Time? A Comparison of Two Cohorts of Welfare Leavers.” Economic Policy Review, September 2001, 7(2), pp. 9-19.

Mayer, Susan E. "Why Welfare Caseloads Fluctuate: A Review of Research On AFDC, SSI, and the Food Stamp Program.” New Zealand Treasury Working Paper 00/7, 2000.

Meyer, Bruce D. and Rosenbaum, Dan T. "Welfare, the Earned Income Tax Credit, and the Labor Supply of Single Mothers.” Quarterly Journal of Economics, August 2001, 16(3), pp. 1063-1114.

Moffitt, Robert. "Incentive Effect of the U.S. Welfare System: A Review." Journal of Economic Literature, March 1992, 30(1), pp. 1-61.

Moffitt, Robert and Rangarajan, Anuradha. "The Effect of Transfer Programmes On Work Effort and Human Capital Formation: Evidence from the U.S," in Andrew Dilnot and Ian Walker, eds., The economics of social security. New York: Oxford University Press, 1989, pp. 116-36. 
Moffitt, Robert A. and Stevens, David. "Changing Caseloads: Macro Influences and Micro Composition.” Economic Policy Review, September 2001, 7(2), pp. 37-51.

Mueser, Peter R. and King, Christopher T. "Urban Welfare-to-Work Transitions in the 1990s." Paper presented at meetings of the Association for Public Policy Analysis and Management, November 2001.

O'Neill, Dave M. and O'Neill, June Ellenoff. Lessons for welfare reform: An analysis of the AFDC caseload and past welfare-to-work programs. Kalamazoo, Mich.: W.E. Upjohn Institute, 1997.

Parrott, Sharon. Welfare recipients who find jobs: What do we know about their employment and earnings? Washington, D.C.: Center on Budget and Policy Priorities, 1998.

Ribar, David C. "Transitions from Welfare and the Employment Prospects of Low-Skill Workers.” Unpublished paper, George Washington University, September 2000.

Troske, Kenneth R. "Evidence on the Employer Size-Wage Premium from WorkerEstablishment Matched Data." The Review of Economics and Statistics, February 1999, 81, pp. 15-26.

Tweedie, Jack; Reichert, Dana and O'Connor, Matthew. "Tracking Recipients After They Leave Welfare: Summaries of New State Tracking Studies.” National Conference of State Legislatures, 1999. (http://www.ncsl.org/statefed/welfare)

Zedlewski, Sheila R. and Alderson, Donald. "Do Families On Welfare in the Post-TANF Era Differ from Their Pre-TANF Counterparts?” Urban Institute Discussion Paper 01-03, February, 2001. 
Table 1: Summary Data for Missouri and the U.S.

\begin{tabular}{|c|c|c|c|c|}
\hline & \multicolumn{2}{|c|}{1991} & \multicolumn{2}{|c|}{1999} \\
\hline & $\mathrm{MO}$ & USA & $\mathrm{MO}$ & USA \\
\hline \multicolumn{5}{|l|}{ Employment by Industry } \\
\hline Mining & 0.2 & 0.6 & 0.2 & 0.4 \\
\hline Construction & 3.8 & 4.3 & 5.1 & 4.9 \\
\hline Manufacturing & 18.1 & 16.9 & 15.1 & 14.3 \\
\hline Transportation and Public Utilities & 6.6 & 5.3 & 6.3 & 5.3 \\
\hline Trade & 23.9 & 23.3 & 23.6 & 23.2 \\
\hline Finance, Insurance, Real Estate & 5.9 & 6.2 & 6.1 & 5.9 \\
\hline Services & 25.2 & 26.4 & 28.3 & 30.3 \\
\hline Government & 16.2 & 16.9 & 15.4 & 15.7 \\
\hline \multicolumn{5}{|l|}{ Race } \\
\hline White & 87.7 & 80.3 & 87.2 & 82.4 \\
\hline Black & 10.7 & 12.1 & 11.3 & 12.8 \\
\hline American Indian, Eskimo, Aleut & 0.4 & 0.8 & 0.4 & 0.9 \\
\hline Asian, Pacific Islander & 0.9 & 2.9 & 1.1 & 4.0 \\
\hline Hispanic Origin* & 1.2 & 9.1 & 1.7 & 11.5 \\
\hline \multicolumn{5}{|l|}{ Income / Earnings } \\
\hline Personal Income (1998 dollars) & 21534 & 23757 & 26012 & 28327 \\
\hline Household Income (1998 dollars) & 34087 & 37343 & 40201 & 38885 \\
\hline Average Weekly Earnings* & 527 & 559 & 740 & 812 \\
\hline Average Hourly Wage*^ & 11.93 & 13.00 & 16.61 & 18.55 \\
\hline Median Hourly Wage * & 9.85 & 11.06 & 13.89 & 14.42 \\
\hline
\end{tabular}

Source: Statistical Abstracts of the United States (1992 and 1999). Employment is calculated for the noninstitutional, civilian population age 16 or over. ${ }^{*}$ Calculated using the March CPS. ${ }^{\wedge}$ topcoded at $\$ 1,000 / \mathrm{hr}$. 
Table 2: Characteristics of Welfare Leavers One and Eight Quarters After Leaving Welfare

\begin{tabular}{|c|c|c|c|c|}
\hline & \multicolumn{2}{|c|}{$1992-1993$} & \multicolumn{2}{|c|}{$1996-1997$} \\
\hline & $\begin{array}{l}\text { 1st Quarter After } \\
\text { Leaving Welfare }\end{array}$ & $\begin{array}{l}\text { 8th Quarter After } \\
\text { Leaving Welfare }\end{array}$ & $\begin{array}{l}\text { 1st Quarter After } \\
\text { Leaving Welfare }\end{array}$ & $\begin{array}{l}\text { 8th Quarter After } \\
\text { Leaving Welfare }\end{array}$ \\
\hline & $(1)$ & $(2)$ & (3) & $(4)$ \\
\hline Percent Employed & 53.0 & 51.4 & 64.0 & 57.9 \\
\hline Number Employed & 16,038 & 15,545 & 24,879 & 22,488 \\
\hline A. Industry of Employment & Percent & Percent & Percent & Percent \\
\hline Agric., Mining, Construction & 1.3 & 1.4 & 1.3 & 1.5 \\
\hline Manufacturing & 13.4 & 14.0 & 9.5 & 10.3 \\
\hline Trans., Com., etc. & 3.1 & 3.6 & 3.0 & 3.9 \\
\hline Wholesale Trade & 2.6 & 2.9 & 2.7 & 2.7 \\
\hline Retail Trade & 27.5 & 25.0 & 28.3 & 25.7 \\
\hline 5311 Dept. Stores & 2.6 & 2.7 & 3.2 & 3.2 \\
\hline 5411 Grocery Stores & 3.4 & 3.1 & 3.5 & 3.3 \\
\hline 5541 Gasoline Stations & 2.4 & 2.5 & 3.2 & 2.9 \\
\hline 5810 Eating \& Drinking Places & 13.8 & 11.6 & 13.1 & 11.1 \\
\hline Finance, Ins., Real Estate & 2.8 & 3.2 & 3.3 & 4.3 \\
\hline Services & 47.3 & 47.2 & 49.9 & 49.1 \\
\hline 7011 Hotels, Motels & 4.6 & 4.1 & 3.9 & 3.5 \\
\hline 7363 Help Supply Services & 5.3 & 6.2 & 8.2 & 6.9 \\
\hline 8051 Skilled Nursing Care & 9.4 & 7.7 & 8.6 & 7.6 \\
\hline 8052 Intermediate Care & 3.0 & 2.1 & 2.0 & 1.6 \\
\hline 8062 Hospitals & 3.2 & 3.7 & 3.1 & 1.6 \\
\hline 8322 Social Services & 1.3 & 1.6 & 2.2 & 2.5 \\
\hline 8361 Residential Care & 1.9 & 2.3 & 1.8 & 2.2 \\
\hline Public Administration & 1.5 & 2.0 & 1.6 & 2.4 \\
\hline Industry Not Ascertained & 0.7 & 0.6 & 0.3 & 0.1 \\
\hline B. Size of Firm & Percent & Percent & Percent & Percent \\
\hline $1-19$ & 11.8 & 11.4 & 10.2 & 10.2 \\
\hline $20-99$ & 22.5 & 20.8 & 20.0 & 20.0 \\
\hline $100-249$ & 19.9 & 18.4 & 18.8 & 18.0 \\
\hline $250-999$ & 21.7 & 22.1 & 22.4 & 23.0 \\
\hline Over 1000 & 24.3 & 27.3 & 28.6 & 28.8 \\
\hline C. Quarterly Earnings in Firm & Percent & Percent & Percent & Percent \\
\hline Below \$2000 & 30.6 & 29.5 & 31.4 & 25.2 \\
\hline$\$ 2000-3999$ & 41.7 & 37.5 & 39.8 & 38.1 \\
\hline$\$ 4000-7500$ & 21.4 & 24.9 & 21.9 & 25.9 \\
\hline Over $\$ 7500$ & 6.3 & 8.1 & 6.9 & 10.8 \\
\hline Mean quarterly earnings & 3404 & 3670 & 3461 & 3988 \\
\hline D. Welfare Recipients in Firm & Percent & Percent & Percent & Percent \\
\hline Less than $2 \%$ & 73.8 & 75.7 & 77.2 & 77.3 \\
\hline $2-10 \%$ & 17.4 & 16.1 & 15.4 & 15.5 \\
\hline Over $10 \%$ & 8.8 & 8.2 & 7.4 & 7.2 \\
\hline
\end{tabular}

Note: All dollars are adjusted for inflation to quarter 2 of 1999. 
Table 3: Characteristics of All Missouri Workers

\begin{tabular}{|c|c|c|c|c|}
\hline & 4th Quarter 1992 & & 4th Quarter 1996 & \\
\hline A. Industry of Employment & Percent & & Percent & \\
\hline Agric., Mining, Construction & 5.6 & & 6.3 & \\
\hline Manufacturing & 19.1 & & 17.1 & \\
\hline Trans., Com., etc. & 6.9 & & 6.7 & \\
\hline Wholesale Trade & 6.3 & & 6.0 & \\
\hline Retail Trade & 19.2 & & 19.4 & \\
\hline 5311 Dept. Stores & & 2.5 & & 2.6 \\
\hline 5411 Grocery Stores & & 2.5 & & 2.4 \\
\hline 5541 Gasoline Stations & & 0.9 & & 0.9 \\
\hline 5810 Eating \& Drinking Places & & 7.0 & & 7.0 \\
\hline Finance, Ins., Real Estate & 5.9 & & 5.8 & \\
\hline Services & 32.5 & & 34.3 & \\
\hline 7011 Hotels, Motels & & 1.3 & & 1.2 \\
\hline 7363 Help Supply Services & & 1.6 & & 2.4 \\
\hline 8051 Skilled Nursing Care & & 1.6 & & 1.6 \\
\hline 8052 Intermediate Care & & 0.6 & & 0.4 \\
\hline 8062 Hospitals & & 4.3 & & 3.9 \\
\hline 8322 Social Services & & 0.5 & & 0.6 \\
\hline 8361 Residential Care & & 0.7 & & 0.7 \\
\hline Public Administration & 4.3 & & 4.2 & \\
\hline Industry Not Ascertained & 0.2 & & 0.2 & \\
\hline B. Size of Firm & Percent & & Percent & \\
\hline$\overline{1-19}$ & 17.4 & & 16.2 & \\
\hline $20-99$ & 21.0 & & 20.7 & \\
\hline $100-249$ & 13.3 & & 13.9 & \\
\hline $250-999$ & 18.1 & & 18.6 & \\
\hline Over 1000 & 30.2 & & 30.7 & \\
\hline C. Quarterly Earnings in Firm & Percent & & Percent & \\
\hline Below \$2000 & 12.1 & & 12.8 & \\
\hline$\$ 2000-3999$ & 20.6 & & 21.1 & \\
\hline$\$ 4000-7500$ & 32.4 & & 34.3 & \\
\hline Over $\$ 7500$ & 35.0 & & 31.8 & \\
\hline Mean quarterly earnings & 6740 & & 6548 & \\
\hline D. Welfare Recipients in Firm & Percent & & Percent & \\
\hline Less than $2 \%$ & 78.5 & & 71.5 & \\
\hline $2-10 \%$ & 19.3 & & 25.3 & \\
\hline Over $10 \%$ & 2.2 & & 3.1 & \\
\hline
\end{tabular}

Note: All dollars are adjusted for inflation to quarter 2 of 1999. 
Table 4: Probit Estimates of Return to Welfare: Marginal Effects

\begin{tabular}{|c|c|c|c|c|c|c|c|c|}
\hline \multirow[t]{2}{*}{$\begin{array}{l}\text { Dependent Variable: Return to } \\
\text { Welfare Within Two Years }\end{array}$} & \multicolumn{4}{|c|}{$1992-1993$} & \multicolumn{4}{|c|}{ 1996-1997 } \\
\hline & (1) & (2) & (3) & (4) & (1) & (2) & (3) & (4) \\
\hline Intercept & $\begin{array}{c}0.7860 \\
(0.0652)\end{array}$ & $\begin{array}{c}0.6784 \\
(0.0702)\end{array}$ & $\begin{array}{c}0.5124 \\
(0.0711)\end{array}$ & $\begin{array}{c}0.6192 \\
(0.1375)\end{array}$ & $\begin{array}{c}0.7035 \\
(0.0587)\end{array}$ & $\begin{array}{c}0.6513 \\
(0.0628)\end{array}$ & $\begin{array}{c}0.4446 \\
(0.0638)\end{array}$ & $\begin{array}{c}0.3896 \\
(0.1068)\end{array}$ \\
\hline Nonwhite* & $\begin{array}{c}0.1057 \\
(0.0166)\end{array}$ & $\begin{array}{c}0.1478 \\
(0.0208)\end{array}$ & $\begin{array}{c}0.1561 \\
(0.0209)\end{array}$ & $\begin{array}{c}0.1570 \\
(0.0211)\end{array}$ & $\begin{array}{c}0.1751 \\
(0.0149)\end{array}$ & $\begin{array}{l}0.2481 \\
(0.0187)\end{array}$ & $\begin{array}{c}0.2616 \\
(0.0188)\end{array}$ & $\begin{array}{c}0.2602 \\
(0.0190)\end{array}$ \\
\hline Years of Education* & $\begin{array}{l}-0.0582 \\
(0.0050)\end{array}$ & $\begin{array}{l}-0.0557 \\
(0.0050)\end{array}$ & $\begin{array}{l}-0.0500 \\
(0.0051)\end{array}$ & $\begin{array}{l}-0.0474 \\
(0.0051)\end{array}$ & $\begin{array}{l}-0.0773 \\
(0.0045)\end{array}$ & $\begin{array}{l}-0.0749 \\
(0.0045)\end{array}$ & $\begin{array}{l}-0.0674 \\
(0.0046)\end{array}$ & $\begin{array}{l}-0.0650 \\
(0.0046)\end{array}$ \\
\hline Age* & $\begin{array}{l}-0.0292 \\
(0.0016)\end{array}$ & $\begin{array}{l}-0.0291 \\
(0.0016)\end{array}$ & $\begin{array}{l}-0.0272 \\
(0.0016)\end{array}$ & $\begin{array}{l}-0.0269 \\
(0.0016)\end{array}$ & $\begin{array}{l}-0.0245 \\
(0.0014)\end{array}$ & $\begin{array}{l}-0.0243 \\
(0.0014)\end{array}$ & $\begin{array}{l}-0.0222 \\
(0.0014)\end{array}$ & $\begin{array}{l}-0.0221 \\
(0.0014)\end{array}$ \\
\hline Number of Children Under 18 & $\begin{array}{c}0.0363 \\
(0.0078)\end{array}$ & $\begin{array}{c}0.0337 \\
(0.0078)\end{array}$ & $\begin{array}{c}0.0375 \\
(0.0078)\end{array}$ & $\begin{array}{c}0.0366 \\
(0.0078)\end{array}$ & $\begin{array}{c}0.0315 \\
(0.0069)\end{array}$ & $\begin{array}{c}0.0275 \\
(0.0069)\end{array}$ & $\begin{array}{c}0.0281 \\
(0.0070)\end{array}$ & $\begin{array}{c}0.0269 \\
(0.0070)\end{array}$ \\
\hline Age of Youngest Child & $\begin{array}{l}-0.0142 \\
(0.0024)\end{array}$ & $\begin{array}{l}-0.1524 \\
(0.0024)\end{array}$ & $\begin{array}{l}-0.0160 \\
(0.0024)\end{array}$ & $\begin{array}{l}-0.0161 \\
(0.0024)\end{array}$ & $\begin{array}{l}-0.0103 \\
(0.0022)\end{array}$ & $\begin{array}{l}-0.0113 \\
(0.0022)\end{array}$ & $\begin{array}{l}-0.0128 \\
(0.0022)\end{array}$ & $\begin{array}{l}-0.0128 \\
(0.0022)\end{array}$ \\
\hline $\begin{array}{l}\text { Time on Welfare in Last } 2 \\
\text { Years* }\end{array}$ & $\begin{array}{c}0.3503 \\
(0.0225)\end{array}$ & $\begin{array}{c}0.3604 \\
(0.0226)\end{array}$ & $\begin{array}{c}0.3404 \\
(0.0300)\end{array}$ & $\begin{array}{c}0.3425 \\
(0.0230)\end{array}$ & $\begin{array}{c}0.2670 \\
(0.0204)\end{array}$ & $\begin{array}{c}0.2923 \\
(0.0206)\end{array}$ & $\begin{array}{c}0.2778 \\
(0.0210)\end{array}$ & $\begin{array}{c}0.2793 \\
(0.0210)\end{array}$ \\
\hline Time Working in Last 2 Years & $\begin{array}{c}0.3418 \\
(0.0230)\end{array}$ & $\begin{array}{c}0.3646 \\
(0.0232)\end{array}$ & $\begin{array}{c}0.3310 \\
(0.0251)\end{array}$ & $\begin{array}{c}0.3324 \\
(0.0252)\end{array}$ & $\begin{array}{c}0.2735 \\
(0.0208)\end{array}$ & $\begin{array}{c}0.2974 \\
(0.0209)\end{array}$ & $\begin{array}{c}0.2737 \\
(0.0225)\end{array}$ & $\begin{array}{c}0.2713 \\
(0.0224)\end{array}$ \\
\hline County Unemployment Rate & & $\begin{array}{c}1.5491 \\
(0.3110)\end{array}$ & $\begin{array}{c}1.5517 \\
(0.3119)\end{array}$ & $\begin{array}{l}1.4996 \\
(0.3127)\end{array}$ & & $\begin{array}{c}1.2087 \\
(0.3793)\end{array}$ & $\begin{array}{l}1.0202 \\
(0.3818)\end{array}$ & $\begin{array}{l}1.0133 \\
(0.3825)\end{array}$ \\
\hline Suburban County & & $\begin{array}{l}-0.0831 \\
(0.0265)\end{array}$ & $\begin{array}{l}-0.0712 \\
(0.2663)\end{array}$ & $\begin{array}{l}-0.0677 \\
(0.0267)\end{array}$ & & $\begin{array}{l}-0.1404 \\
(0.0245)\end{array}$ & $\begin{array}{l}-0.1313 \\
(0.0247)\end{array}$ & $\begin{array}{l}-0.1287 \\
(0.0247)\end{array}$ \\
\hline Urban County & & $\begin{array}{l}-0.0868 \\
(0.0208)\end{array}$ & $\begin{array}{l}-0.0611 \\
(0.0209)\end{array}$ & $\begin{array}{l}-0.0478 \\
(0.0212)\end{array}$ & & $\begin{array}{l}-0.1600 \\
(0.0187)\end{array}$ & $\begin{array}{l}-0.1208 \\
(0.0189)\end{array}$ & $\begin{array}{l}-0.1154 \\
(0.0191)\end{array}$ \\
\hline $\begin{array}{l}\text { Earnings In Quarter After } \\
\text { Leaving Welfare }\end{array}$ & & & & & & & & \\
\hline$\$ 1-\$ 499$ & & & $\begin{array}{c}0.2359 \\
(0.0304)\end{array}$ & $\begin{array}{c}0.1492 \\
(0.1140)\end{array}$ & & & $\begin{array}{c}0.2797 \\
(0.0274)\end{array}$ & $\begin{array}{c}0.3092 \\
(0.0823)\end{array}$ \\
\hline$\$ 500-\$ 999$ & & & $\begin{array}{c}0.2009 \\
(0.0345)\end{array}$ & $\begin{array}{c}0.1102 \\
(0.1152)\end{array}$ & & & $\begin{array}{c}0.3151 \\
(0.0298)\end{array}$ & $\begin{array}{c}0.3490 \\
(0.0838)\end{array}$ \\
\hline$\$ 1000-\$ 1999$ & & & $\begin{array}{c}0.2328 \\
(0.0225)\end{array}$ & $\begin{array}{c}0.1408 \\
(0.1131)\end{array}$ & & & $\begin{array}{c}0.2532 \\
(0.0211)\end{array}$ & $\begin{array}{c}0.2900 \\
(0.0815)\end{array}$ \\
\hline$\$ 2000-\$ 2999$ & & & $\begin{array}{c}0.0527 \\
(0.0229)\end{array}$ & $\begin{array}{l}-0.0336 \\
(0.1133)\end{array}$ & & & $\begin{array}{c}0.1012 \\
(0.0207)\end{array}$ & $\begin{array}{c}0.1350 \\
(0.0819)\end{array}$ \\
\hline$\$ 3000-\$ 3999$ & & & $\begin{array}{l}-0.1957 \\
(0.0349)\end{array}$ & $\begin{array}{l}-0.2613 \\
(0.1165)\end{array}$ & & & $\begin{array}{l}-0.0958 \\
(0.0258)\end{array}$ & $\begin{array}{l}-0.0499 \\
(0.0834)\end{array}$ \\
\hline$\$ 4000$ Or More & & & $\begin{array}{l}-0.4371 \\
(0.0539)\end{array}$ & $\begin{array}{l}-0.5006 \\
(0.1231)\end{array}$ & & & $\begin{array}{l}-0.3608 \\
(0.0335)\end{array}$ & $\begin{array}{c}-0.3035 \\
(0.0864)\end{array}$ \\
\hline Indust & No & No & No & Yes & No & No & No & Yes \\
\hline Controls for Firm Size & No & No & No & Yes & No & No & No & Yes \\
\hline $\mathrm{N}$ & 30092 & 30092 & 30092 & 30092 & 38721 & 38721 & 38721 & 38721 \\
\hline Log Likelihood & -18883.81 & -18851.32 & -18685.56 & -18660.24 & -22717.87 & -22663.00 & -22372.89 & -22346.09 \\
\hline
\end{tabular}

Note: Standard errors are in parenthesis. * indicates that the value of the coefficient in Column (4) for the 1996-1997 cohort is significantly different from the value of the coefficient for the 1992-1993 cohort at the $1 \%$ significance level. 
Table 5: Probability of Returning to Welfare Within Two Years For Various Attributes

\begin{tabular}{|c|c|c|c|c|}
\hline \multirow{2}{*}{$\begin{array}{l}\text { Specification in Table } 3 \\
\text { Predicted Probability for Various Groups }\end{array}$} & \multicolumn{2}{|c|}{ 1992-1993 Cohort } & \multicolumn{2}{|c|}{ 1996-1997 Cohort } \\
\hline & $(1)$ & (4) & $(1)$ & (4) \\
\hline Average Individual in Sample & 0.361 & 0.349 & 0.289 & 0.290 \\
\hline Average Individual in Cohort & 0.376 & 0.354 & 0.292 & 0.288 \\
\hline White & 0.347 & 0.329 & 0.268 & 0.259 \\
\hline Nonwhite & 0.387 & 0.387 & 0.328 & 0.350 \\
\hline One Child Under 18 & 0.349 & 0.337 & 0.279 & 0.282 \\
\hline Four Children Under 18 & 0.390 & 0.378 & 0.312 & 0.310 \\
\hline 4.0 Percent County Unemployment Rate & & 0.340 & & 0.285 \\
\hline 7.5 Percent County Unemployment Rate & & 0.360 & & 0.297 \\
\hline Years of Education $=9$ & 0.414 & 0.391 & 0.354 & 0.344 \\
\hline Years of Education $=12$ & 0.347 & 0.338 & 0.272 & 0.276 \\
\hline Percent on AFDC Previous 8 Quarters $=0$ & 0.287 & 0.278 & 0.238 & 0.236 \\
\hline Percent on AFDC Previous 8 Quarters $=1$ & 0.416 & 0.403 & 0.327 & 0.331 \\
\hline Percent Working Previous 8 Quarters $=0$ & 0.310 & 0.300 & 0.251 & 0.253 \\
\hline Percent Working Previous 8 Quarters $=1$ & 0.438 & 0.423 & 0.346 & 0.347 \\
\hline No Job when Leaving & & 0.354 & & 0.259 \\
\hline Job with Quarterly Earnings $\$ 1-\$ 500$ & & 0.411 & & 0.368 \\
\hline Job with Quarterly Earnings $\$ 3001-\$ 4000$ & & 0.262 & & 0.244 \\
\hline
\end{tabular}

Note: The probability is predicted using the mean value of attributes across both cohorts. 
Table A-1: Means of Variables Used in Estimation

\begin{tabular}{|c|c|c|c|}
\hline & $\begin{array}{c}1992-1993 \\
(1)\end{array}$ & $\begin{array}{c}1996-1997 \\
(2)\end{array}$ & $\begin{array}{c}\text { Both Cohorts } \\
\text { (3) }\end{array}$ \\
\hline Return to Welfare Within 2 Years & 0.36 & 0.30 & 0.33 \\
\hline Nonwhite & 0.34 & 0.37 & 0.36 \\
\hline Years of Education & 11.32 & 11.38 & 11.36 \\
\hline Age & 29.11 & 29.63 & 29.40 \\
\hline \multicolumn{4}{|l|}{ Number of Children Lees } \\
\hline Than 18 & 1.89 & 1.90 & 1.90 \\
\hline Age of Youngest Child & 5.13 & 5.50 & 5.34 \\
\hline Time on Welfare in Last 2 Years & 0.55 & 0.62 & 0.59 \\
\hline Time Working in Last 2 Years & 0.38 & 0.44 & 0.41 \\
\hline County Unemployment Rate & 0.06 & 0.05 & 0.06 \\
\hline Suburban County & 0.11 & 0.11 & 0.11 \\
\hline Urban County & 0.40 & 0.41 & 0.41 \\
\hline $\begin{array}{l}\text { Zero Earnings in Quarter After } \\
\text { Leaving } 0 \text { (No Job) } \\
\text { Earnings In Quarter After }\end{array}$ & 0.47 & 0.36 & 0.41 \\
\hline Leaving Between \$1-\$499 & 0.07 & 0.07 & 0.07 \\
\hline $\begin{array}{l}\text { Earnings In Quarter After } \\
\text { Leaving Between } \$ 500-\$ 999 \\
\text { Earnings In Quarter After }\end{array}$ & 0.05 & 0.06 & 0.06 \\
\hline $\begin{array}{l}\text { Leaving Between } \$ 1000-\$ 1999 \\
\text { Earnings In Quarter After }\end{array}$ & 0.16 & 0.16 & 0.16 \\
\hline Leaving Between \$2000-\$2999 & 0.16 & 0.18 & 0.17 \\
\hline $\begin{array}{l}\text { Earnings In Quarter After } \\
\text { Leaving Between } \$ 3000-\$ 3999 \\
\text { Earnings In Quarter After }\end{array}$ & 0.06 & 0.10 & 0.09 \\
\hline Leaving $\$ 4000$ Or More & 0.03 & 0.07 & 0.05 \\
\hline $\mathrm{N}$ & 30092 & 38721 & 68813 \\
\hline
\end{tabular}

Note: The means in column (3) are the ones used to construct the figures in Table 5 
Figure 1: Unemployment Rate for Women Age 20-60

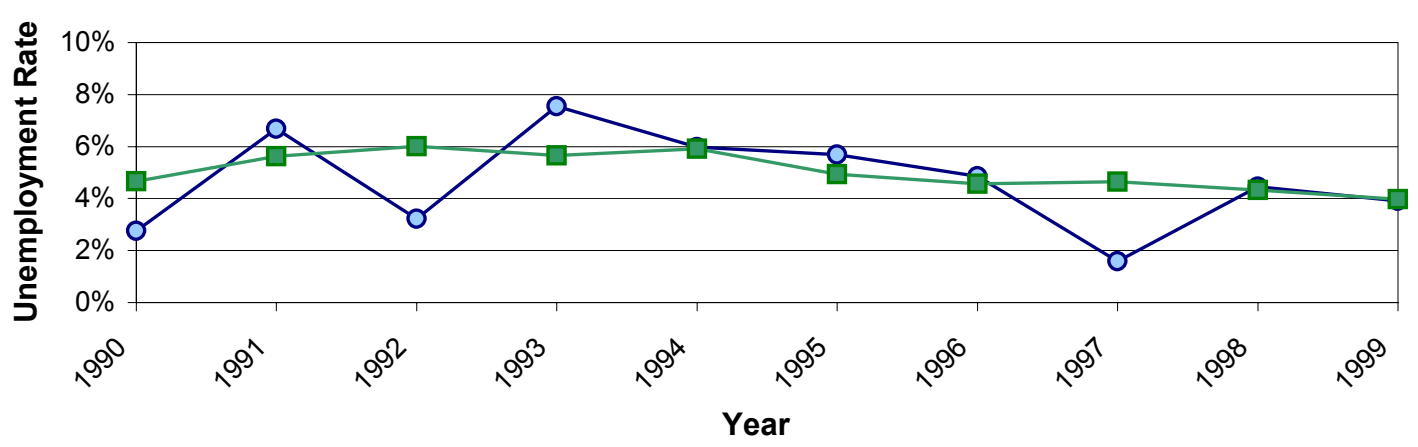

Figure 2: Median Hourly Wage by Year Women Age 20-60

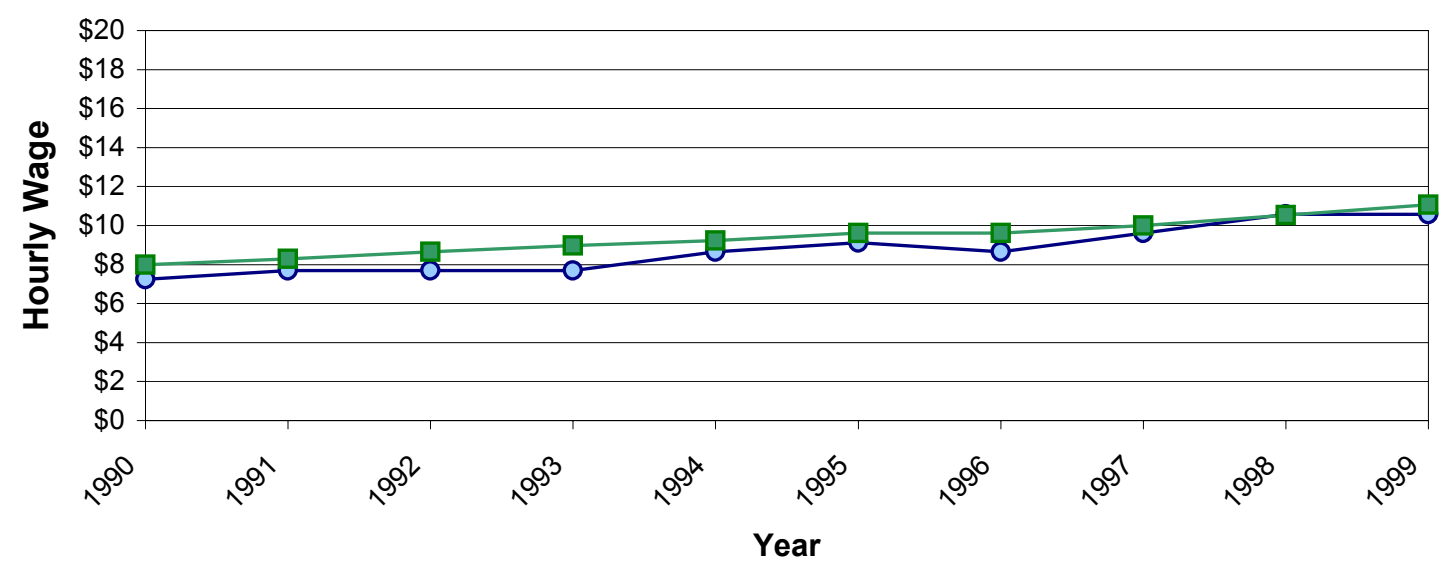

Figure 3: 25th Percentile of Hourly Wage by Year Women Age 20-60

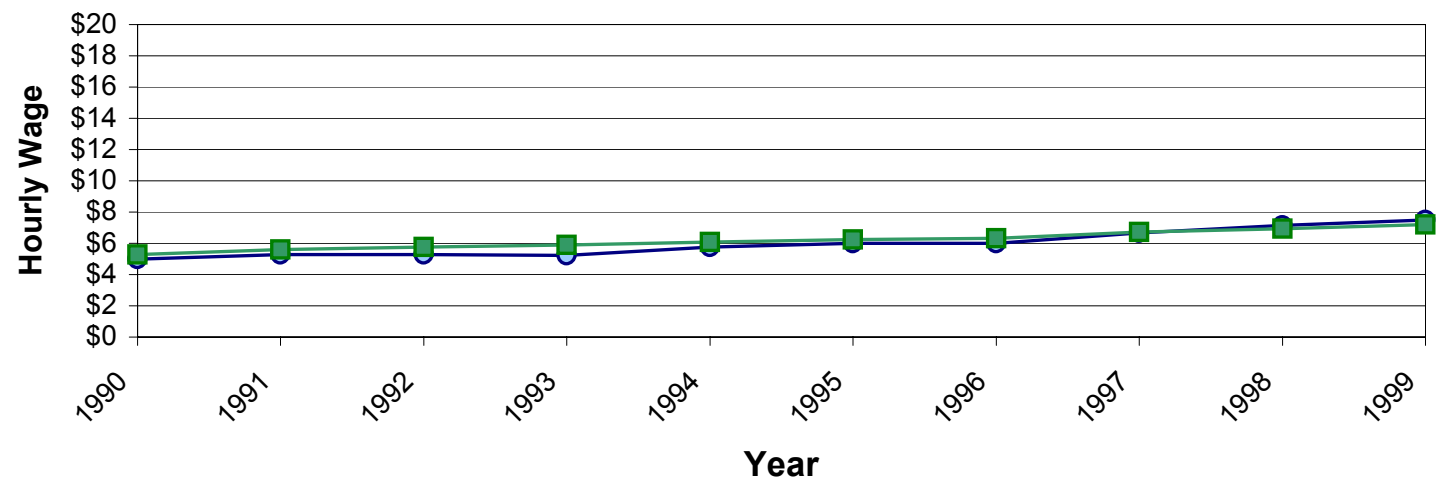

$$
\text { -0-Missouri }-\square-\text { USA }
$$

Source: CPS March Supplement 1990-1999 
Figure 4: Caseload, Leavers, Arrivals: Moving Average

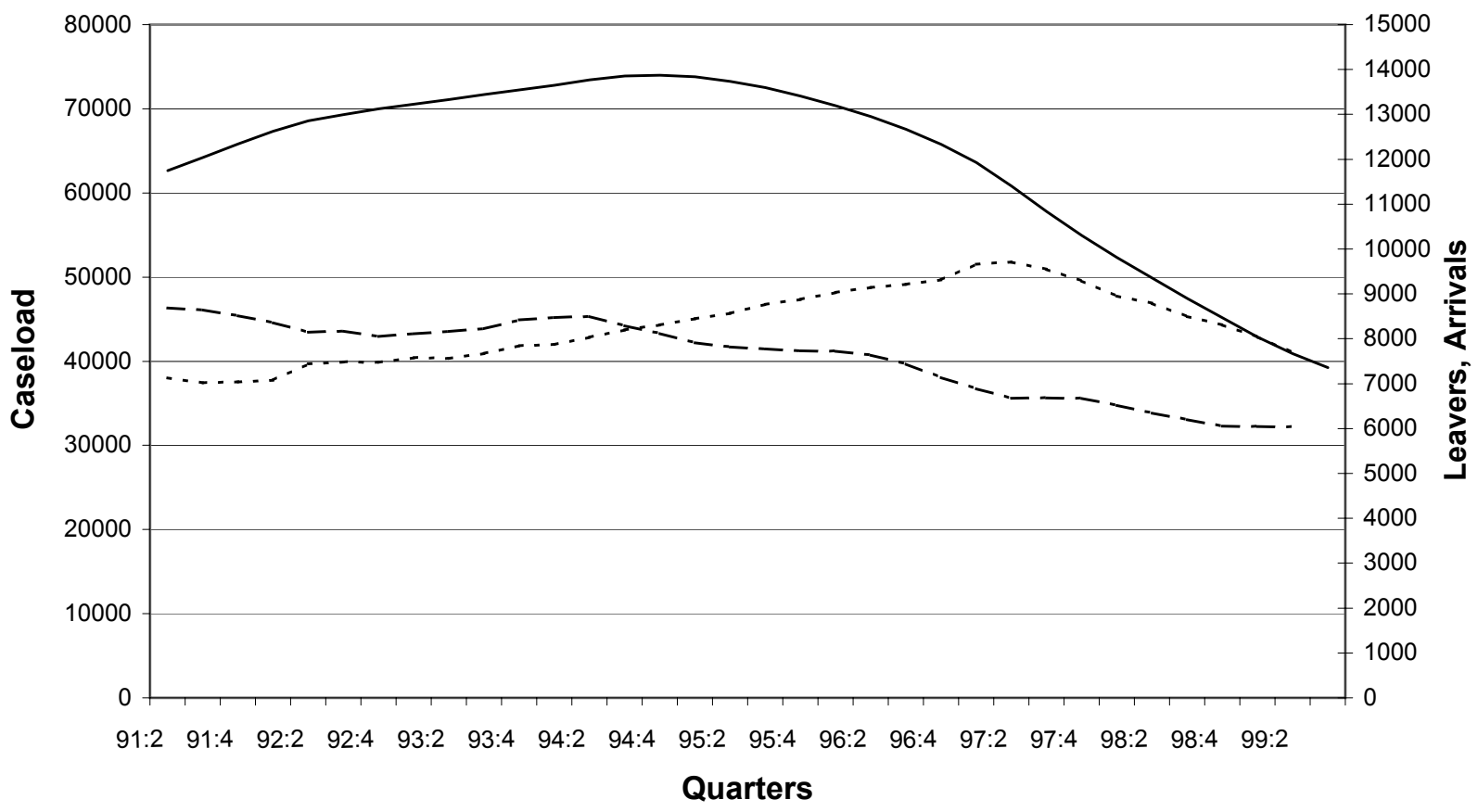

Caseload - . - . - Leavers - - - Arrivals

Figure 5: Exit Rate: Moving Average

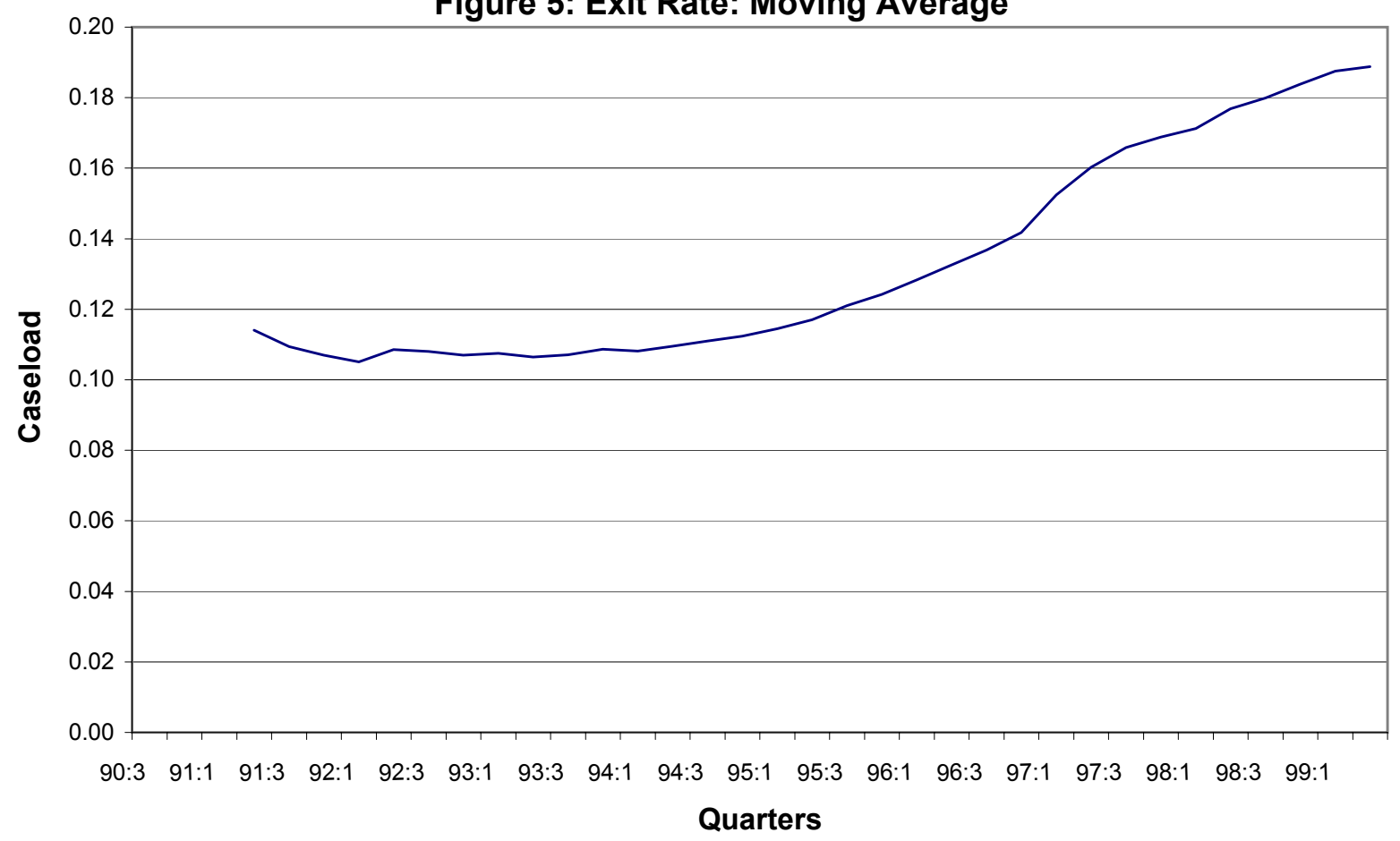

Note: All measures calculated as four-quarter moving averages 
Figure 6: Characteristics of Recipients, Arrivals and Leavers: Moving Average
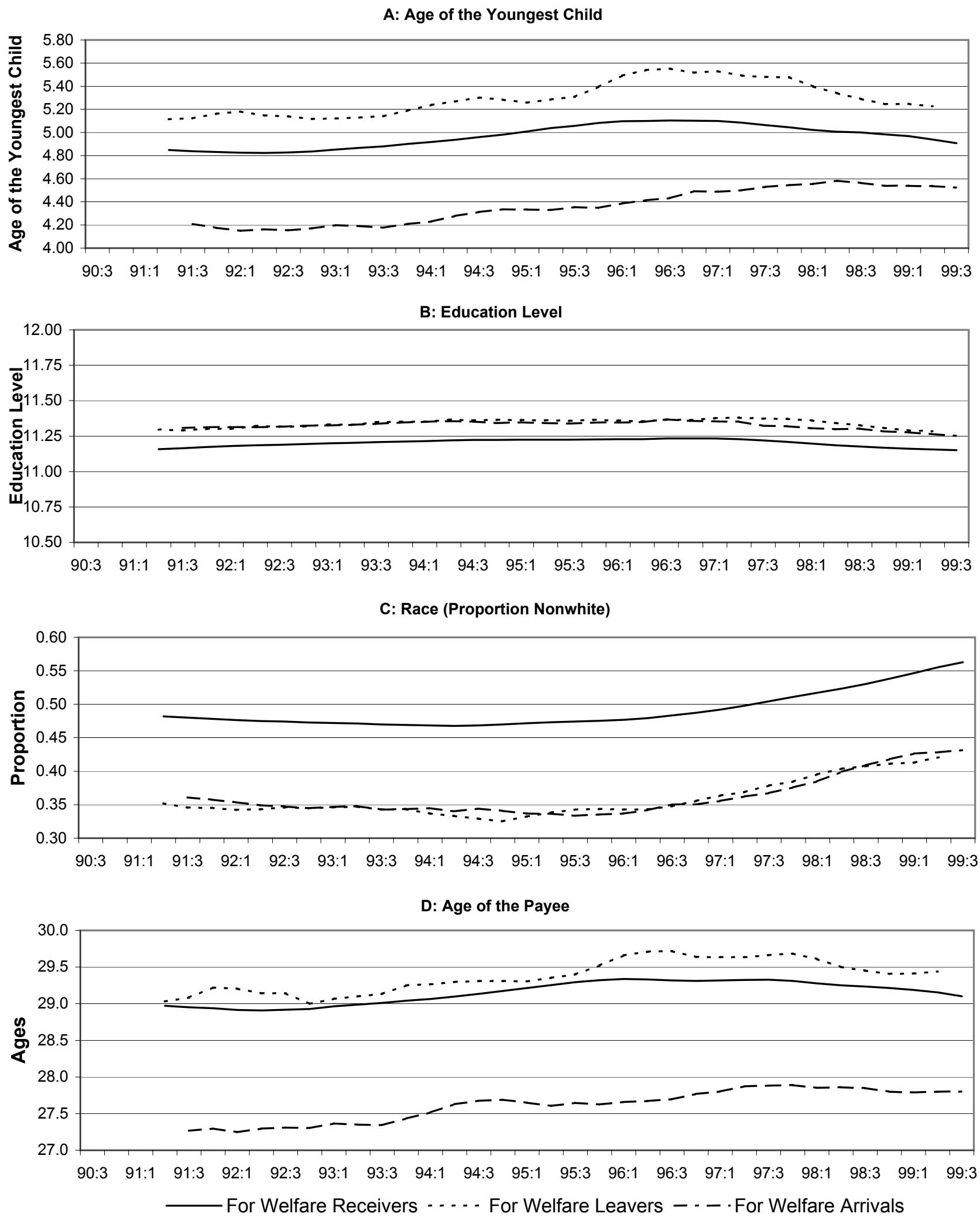

Note: All measures calculated as four-quarter moving averages 
Figure 7: Welfare and Employment History: Moving Average

A: Proportion of Prior Eight Quarters on Welfare

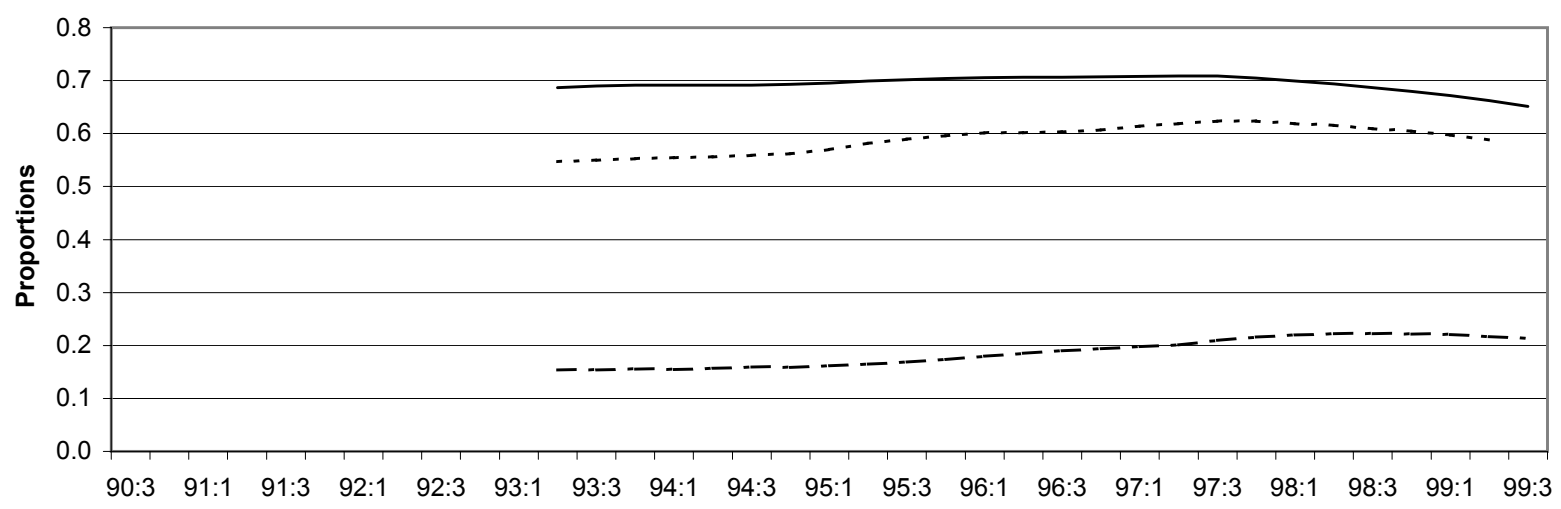

B: Fraction of Income in Prior Eight Quarters Due to Welfare

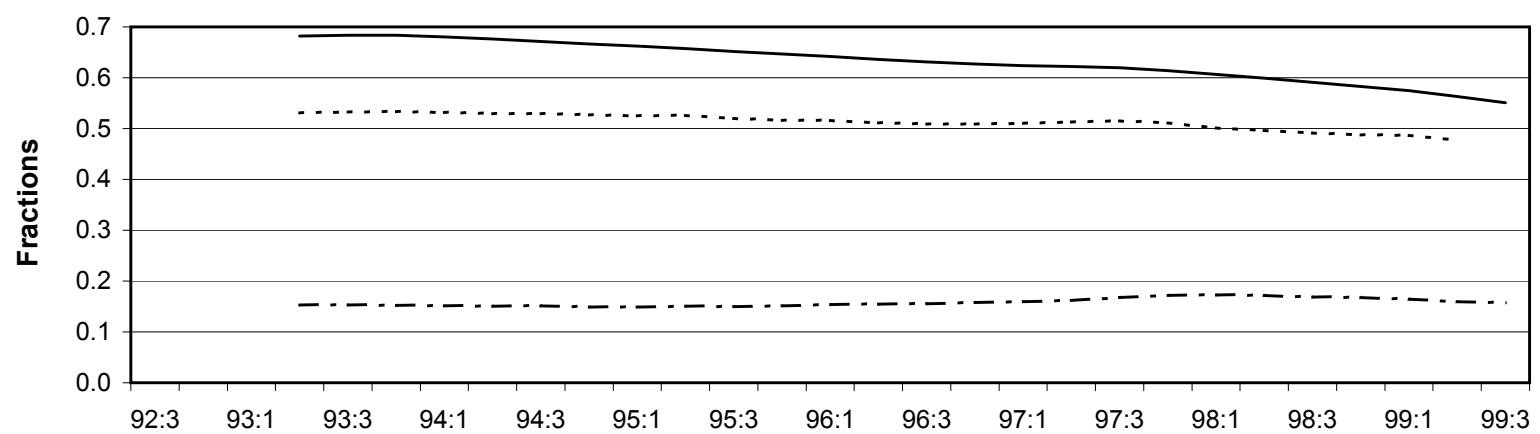

C: Proportion of Prior Eight Quarters With Positive Earnings

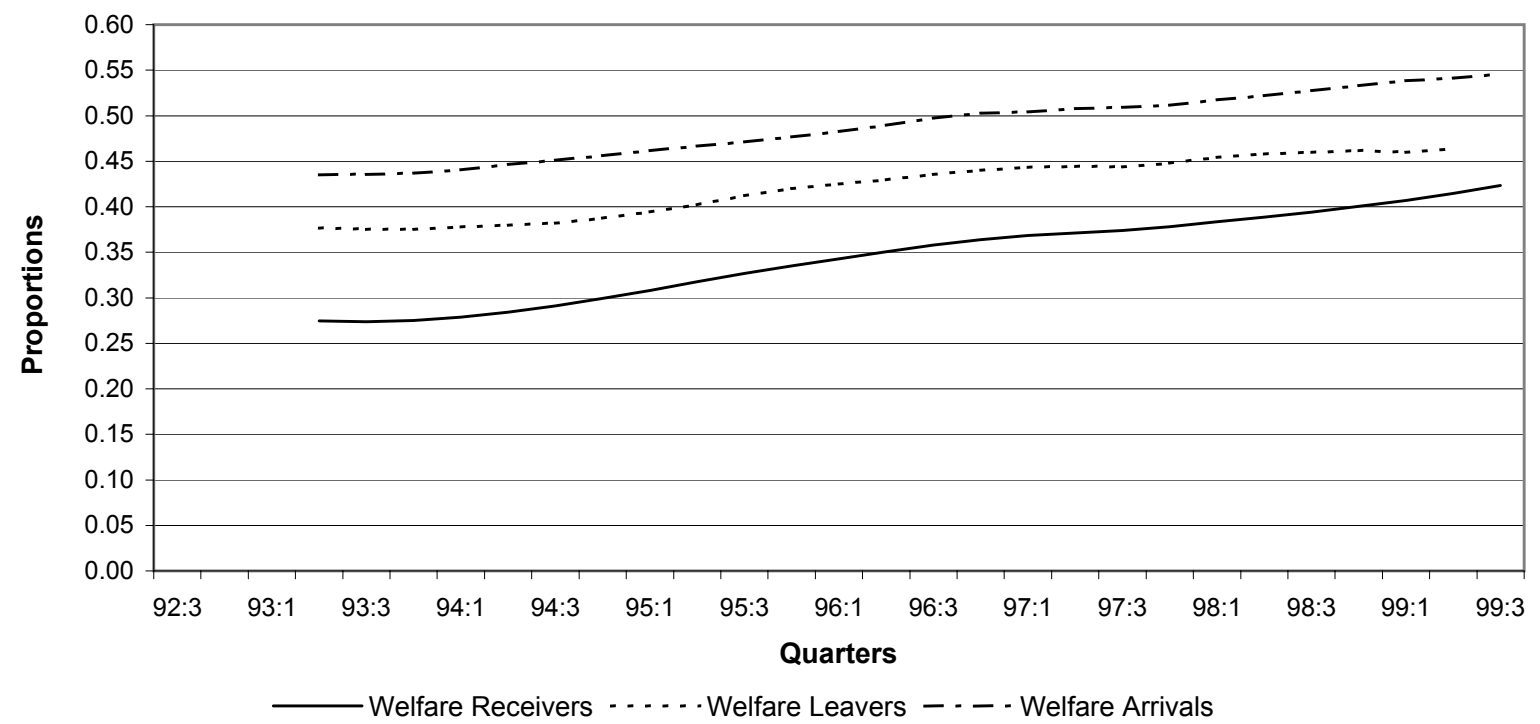

Note: All measures calculated as four-quarter moving averages 
Figure 8: Employment and Recidivism for the Two Cohorts

A: Percentage of Leavers Back on Welfare in Each of the Following Eight Quarters For the Two Groups

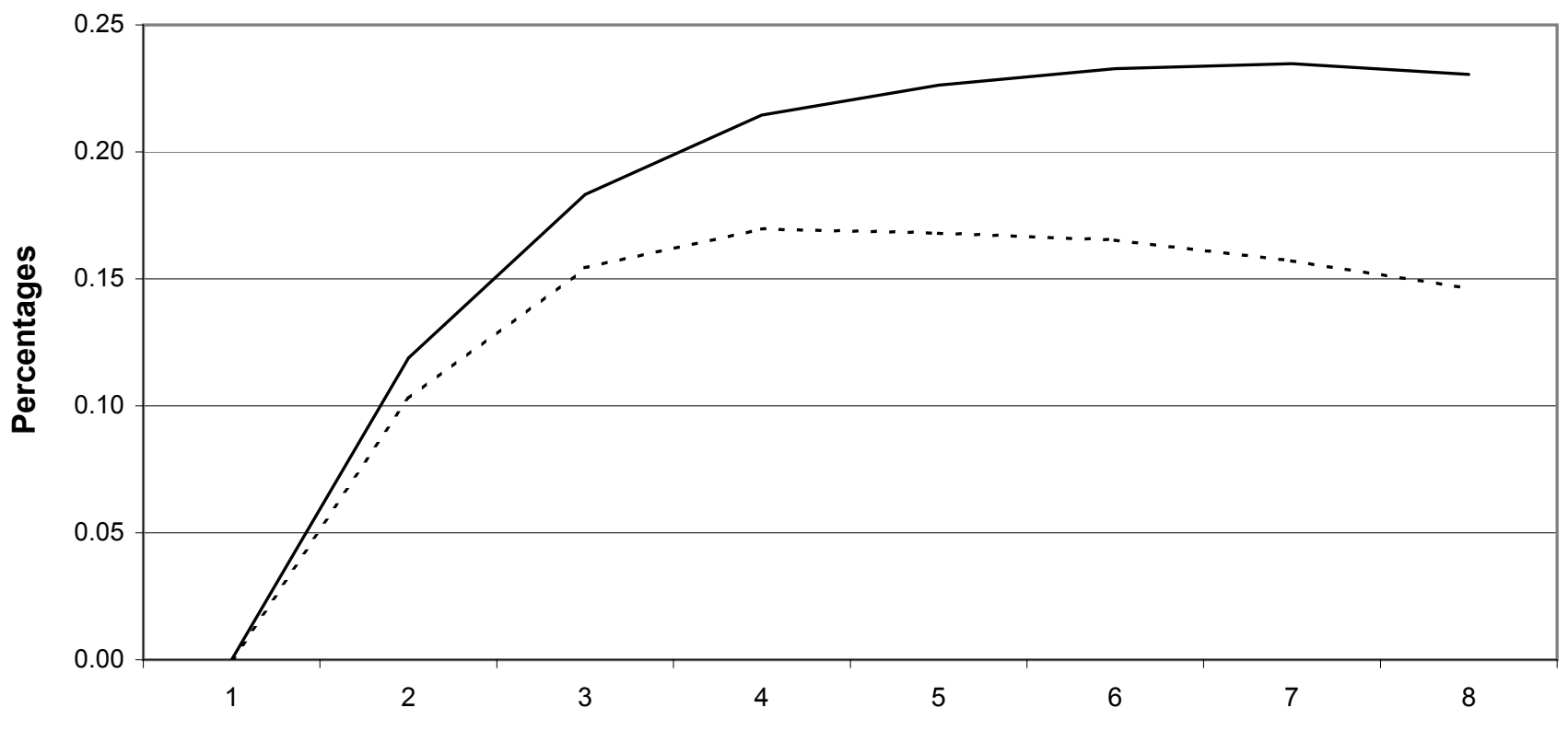

B: Employment Rate of the Leavers in the Following Eight Quarters for the Two Groups

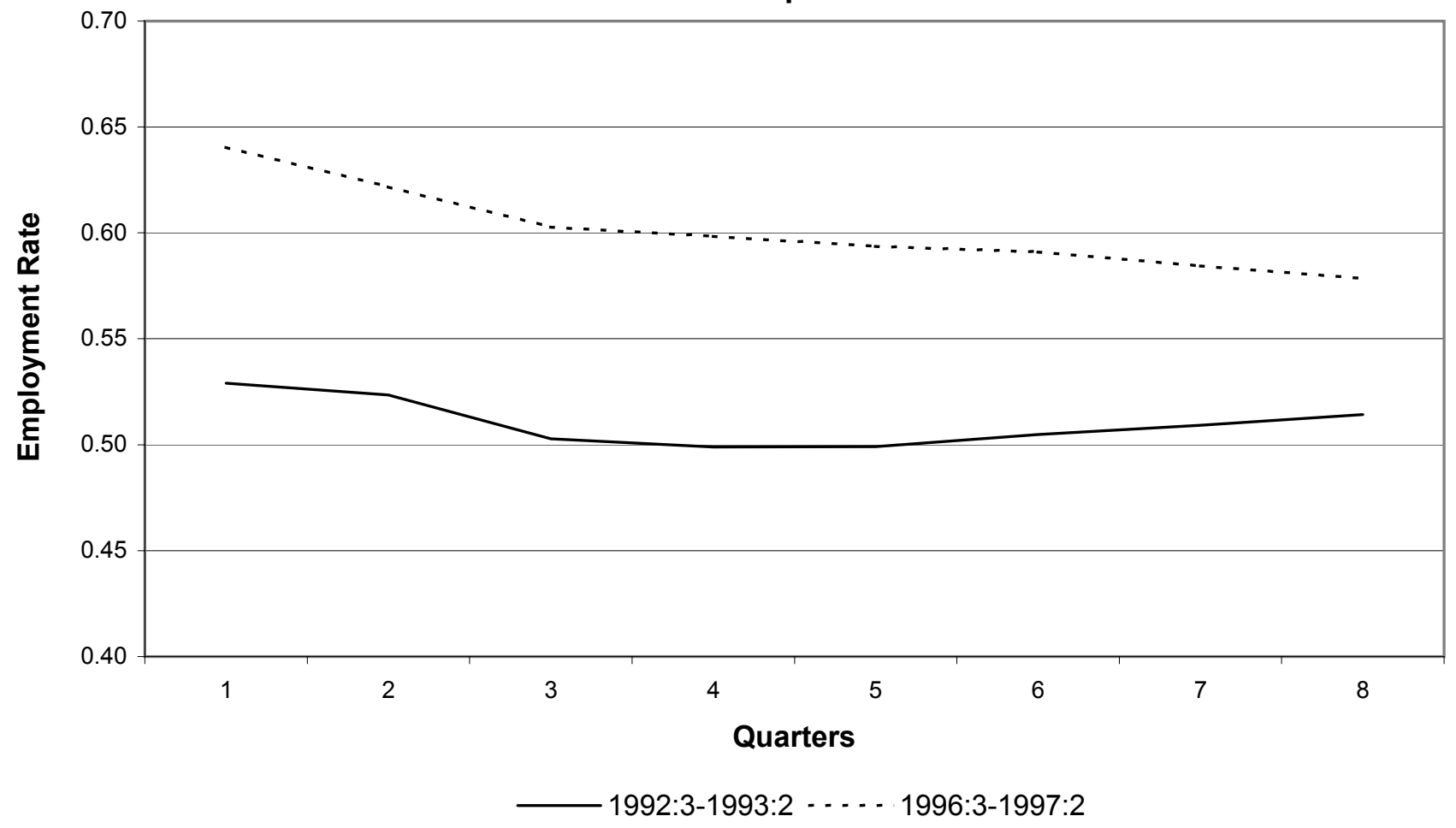

Note: All measures calculated as four-quarter moving averages 
Figure 9: Mean Earnings (adjusted to 99:2) of the Leavers in Each of the Following Eight Quarters For the Two Cohorts
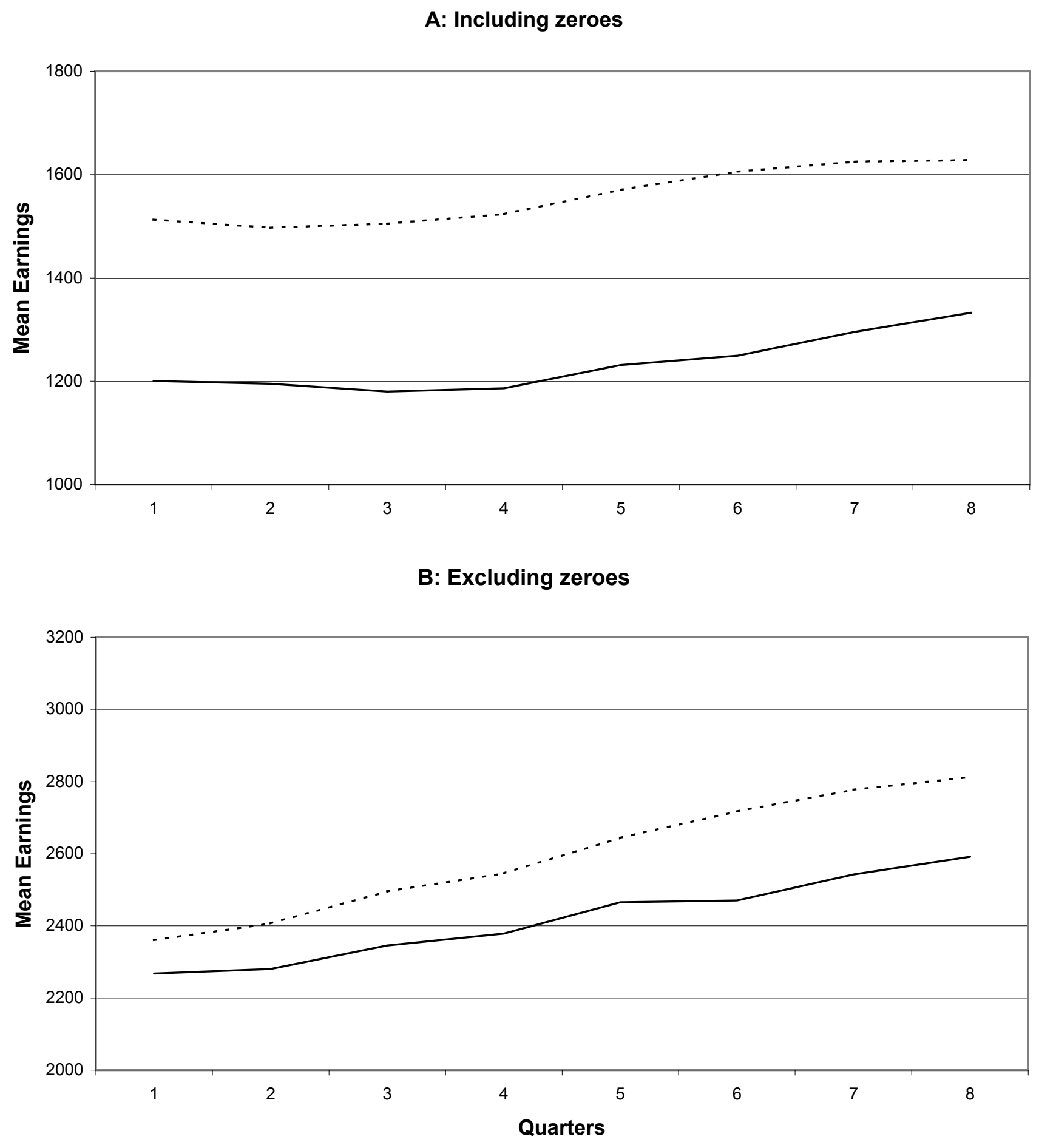

1992:3-1993:2 - - 1996:3-1997:2

Note: All measures calculated as four-quarter moving averages 
Figure A-1: Caseload, Leavers, Arrivals

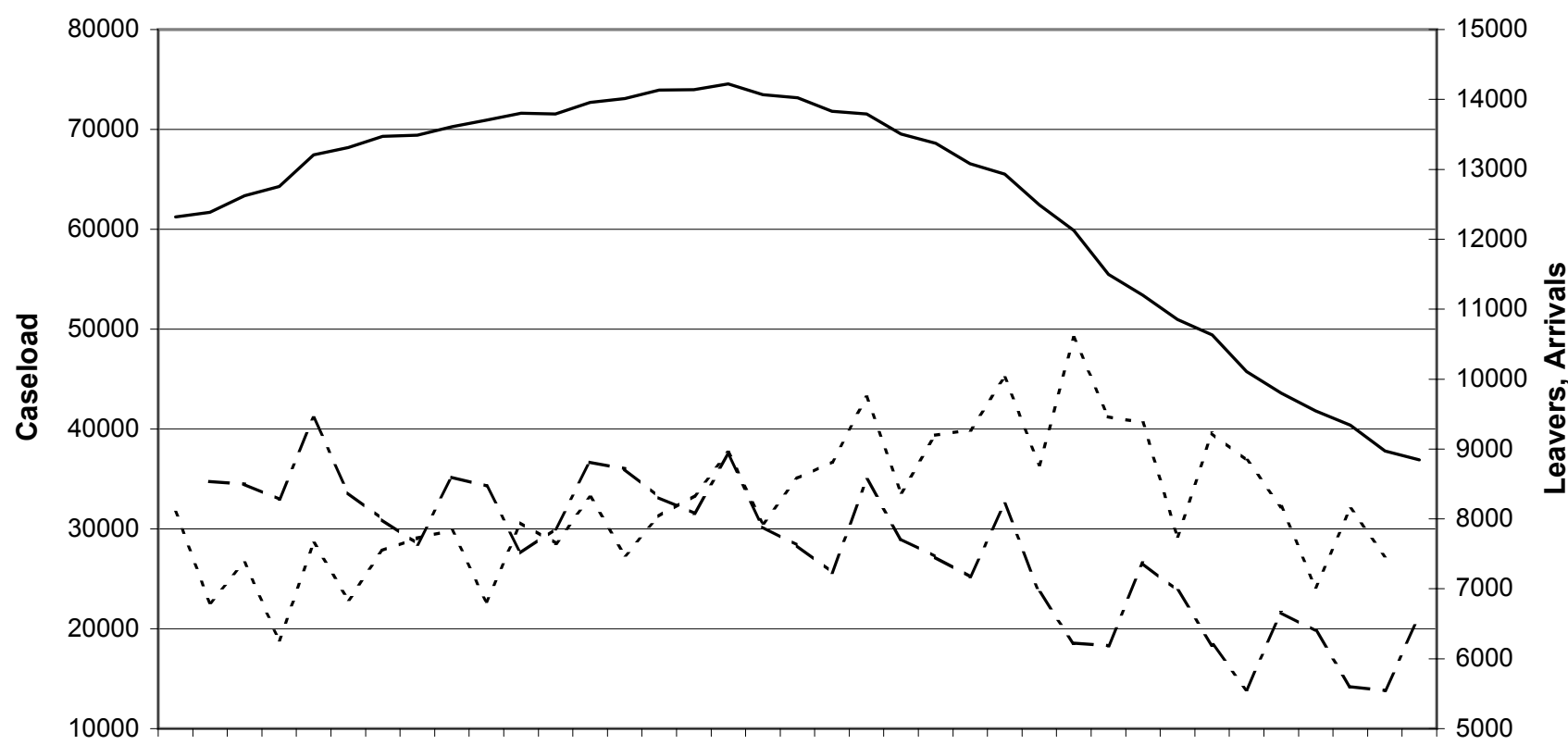

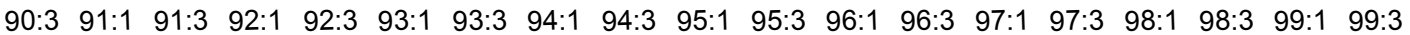

Quarters

Caseload -... Leavers - - - Arrivals

Figure A-2: Exit Rate

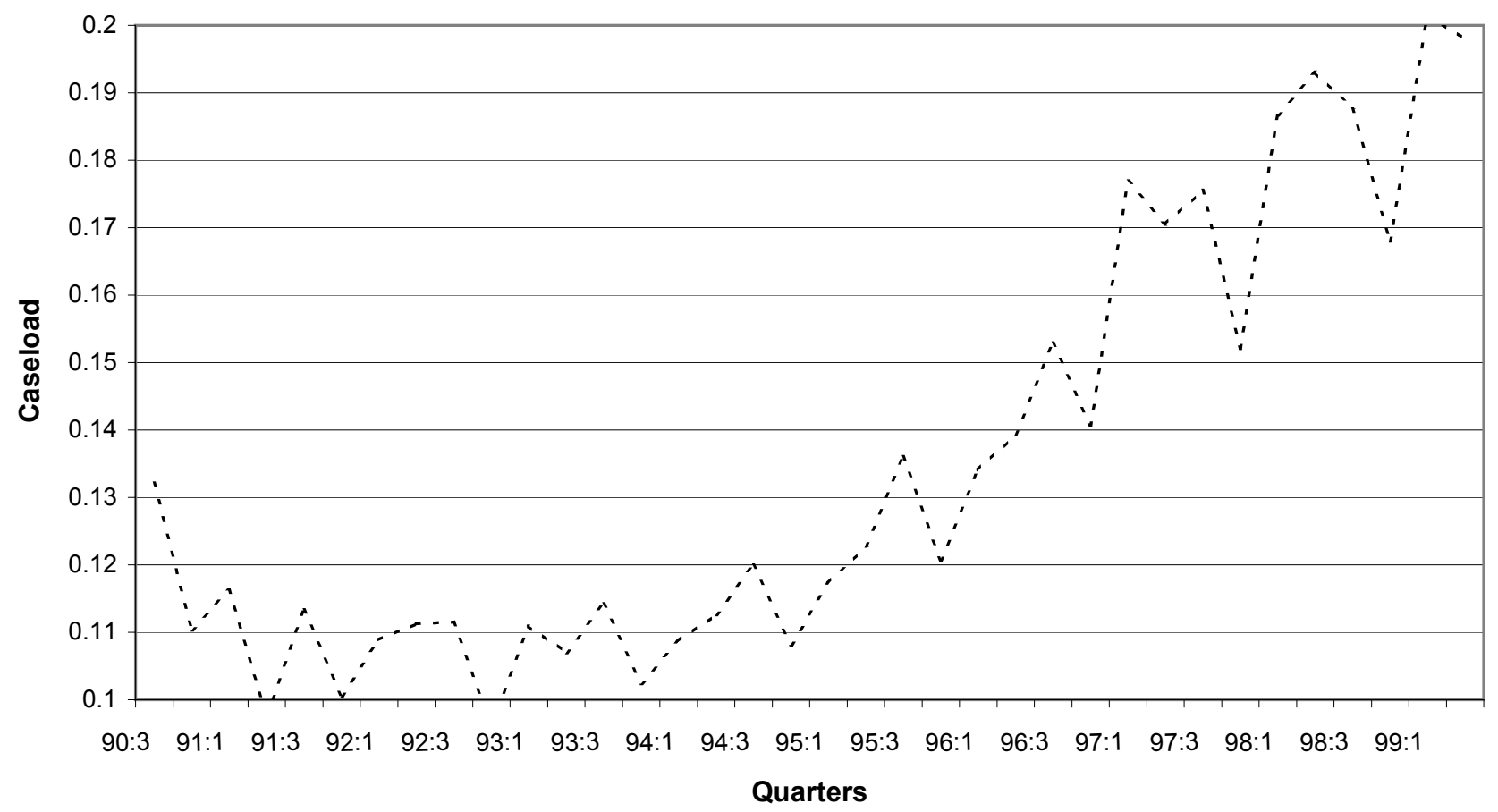


Figure A-3: Characteristics of Recipients, Arrivals and Leavers

A: Age of the Youngest Child

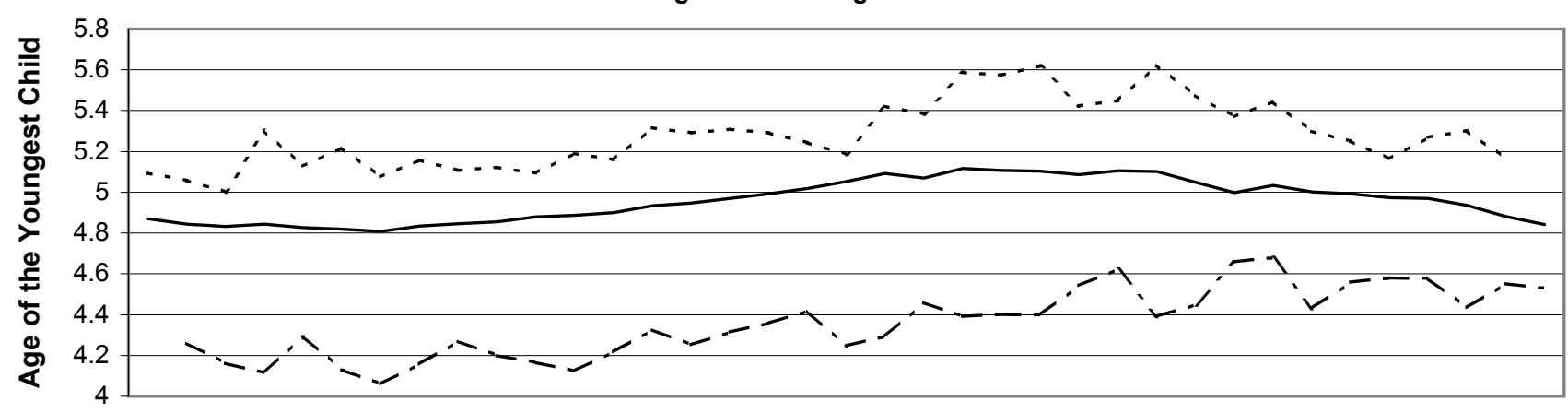

B: Education Level

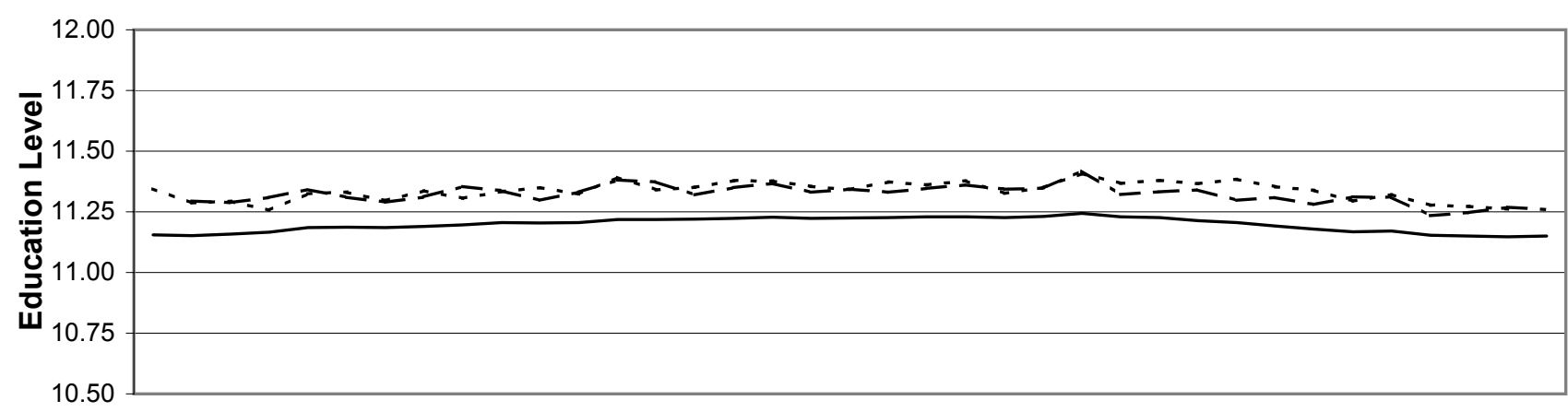

C: Race (Percent of Nonwhite)

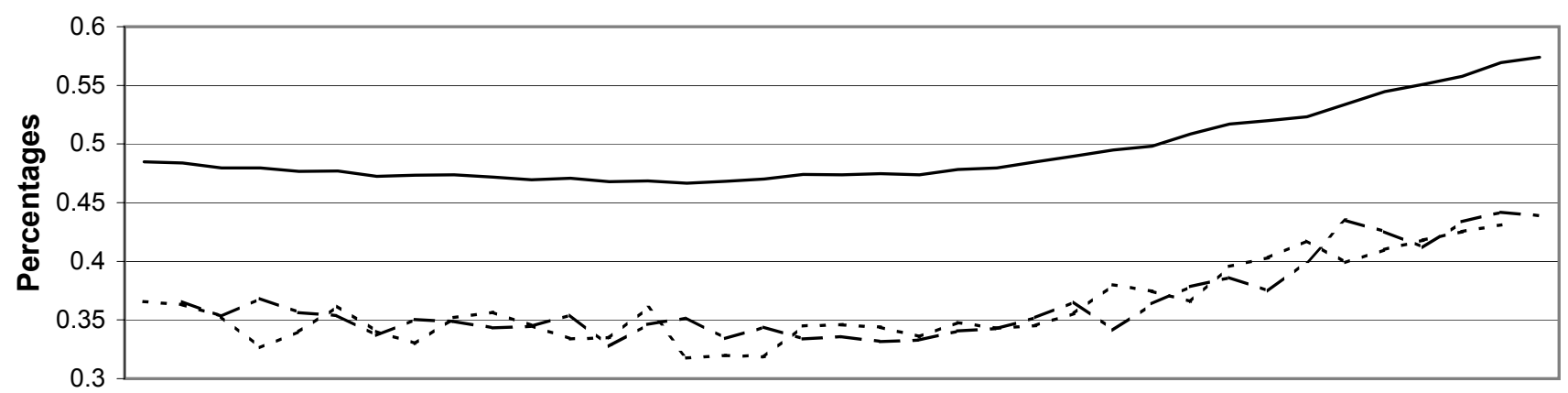

D: Age of the Payee

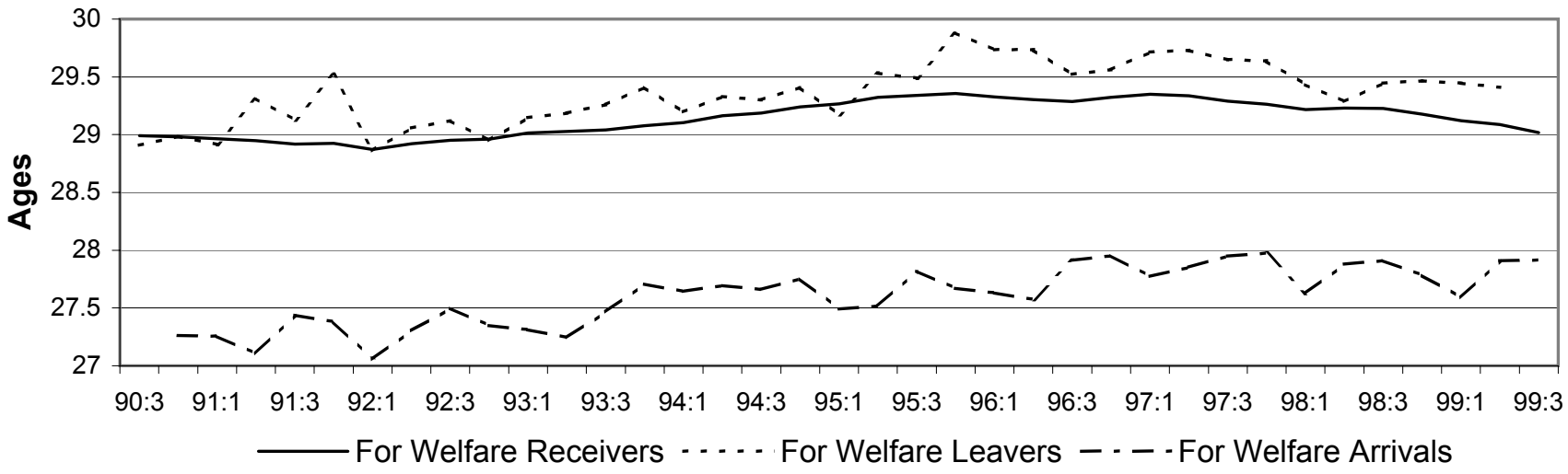


Figure A-4: Arrivals and Leavers by Race

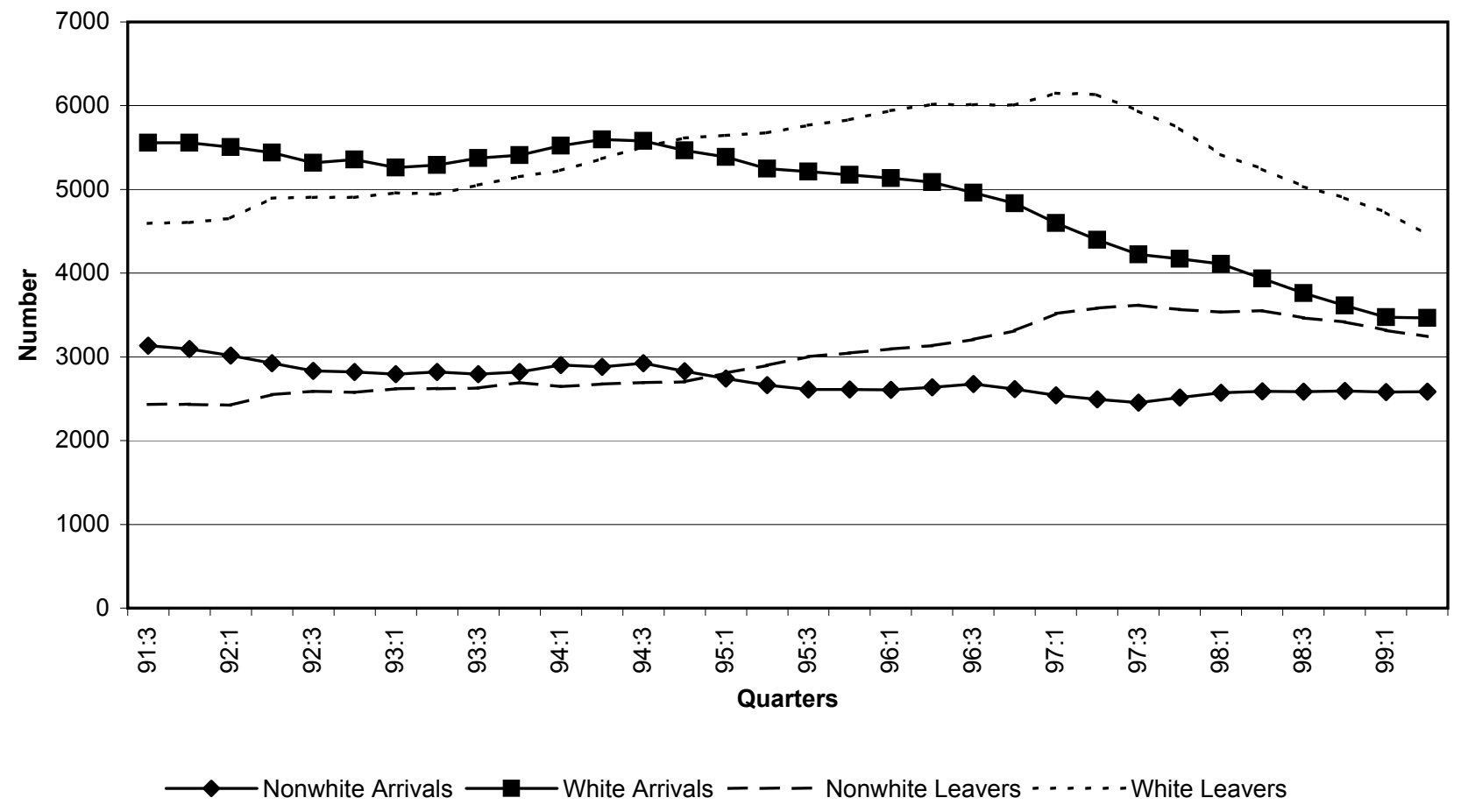

Figure A-5: Exit Rate by Race

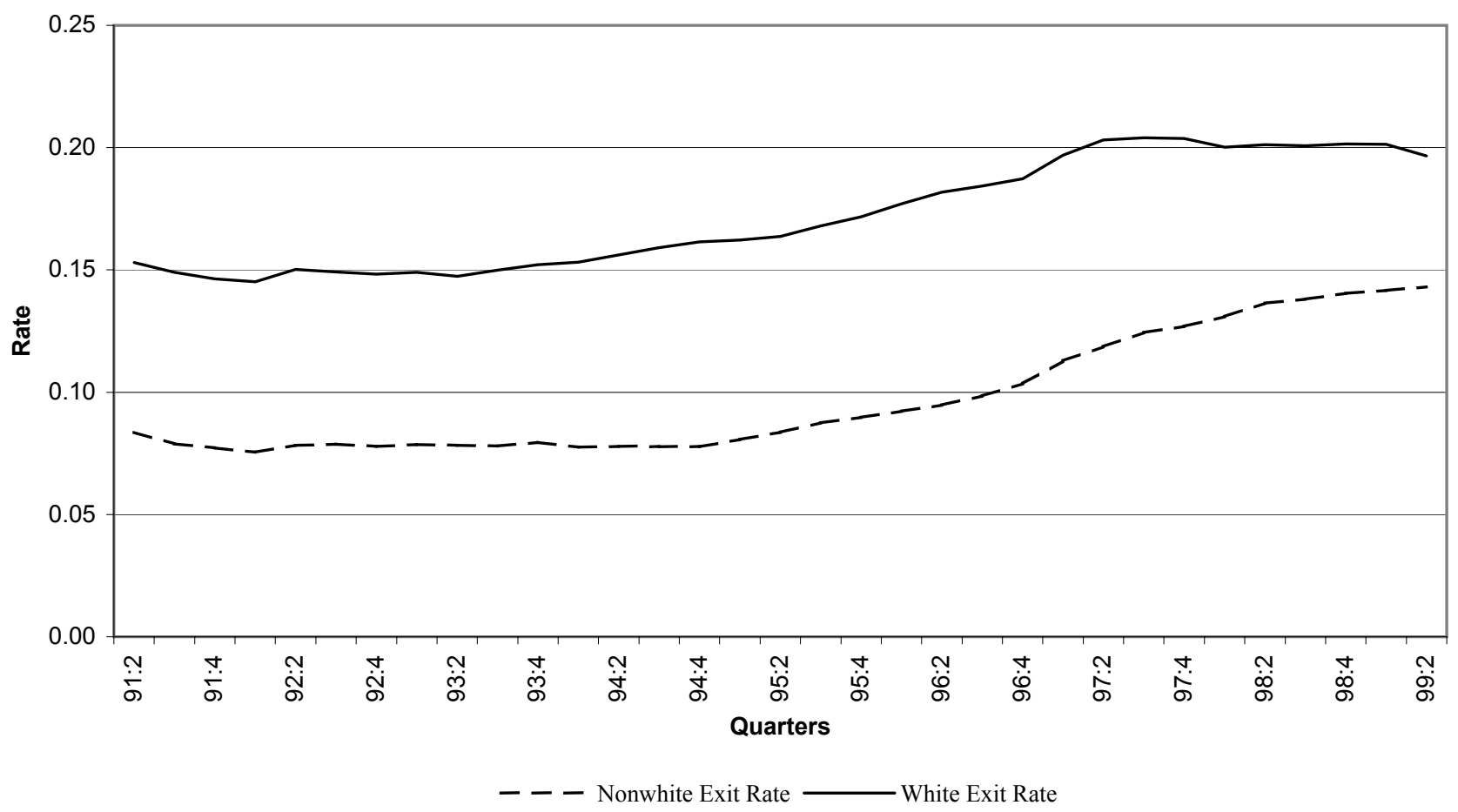


Figure A-6: Welfare and Employment History

A: Proportion of Prior Eight Quarters on Welfare

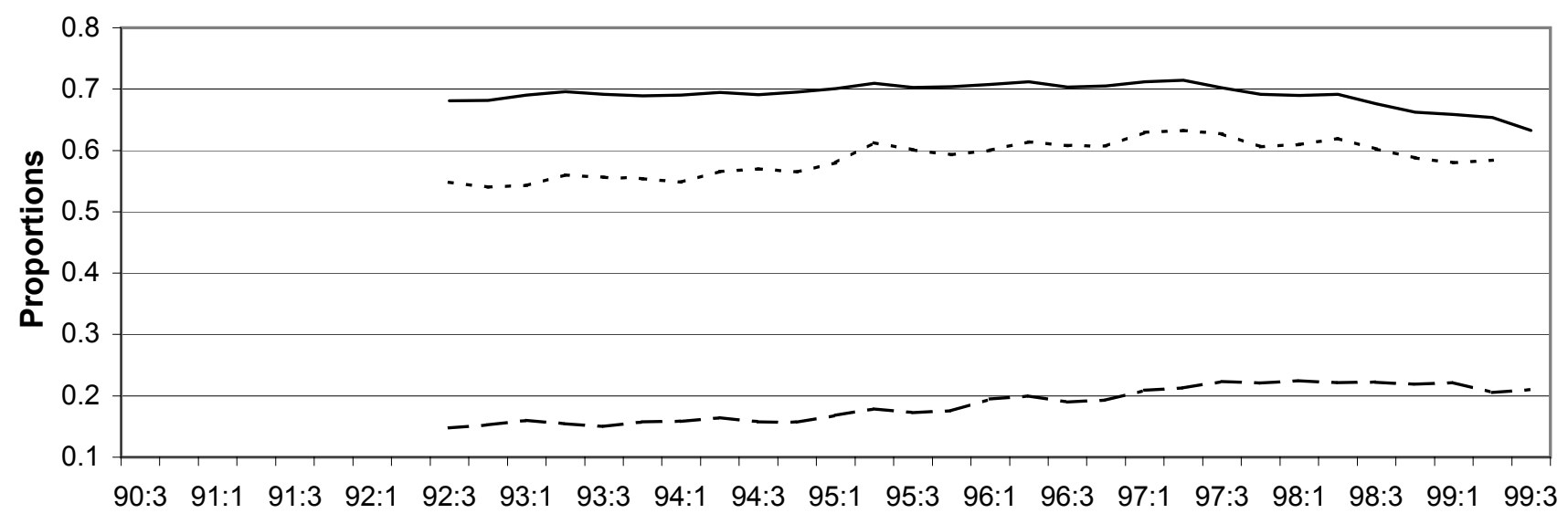

B: Fraction of Income in Prior Eight Quarters Due to Welfare

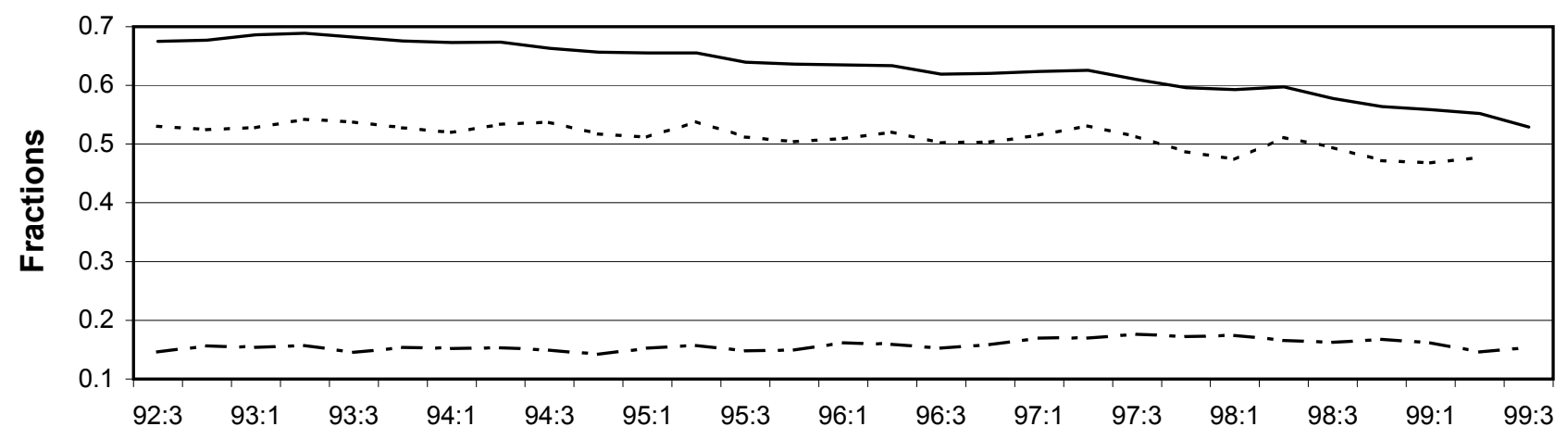

B: Proportion of Prior Eight Quarters With Positive Earnings

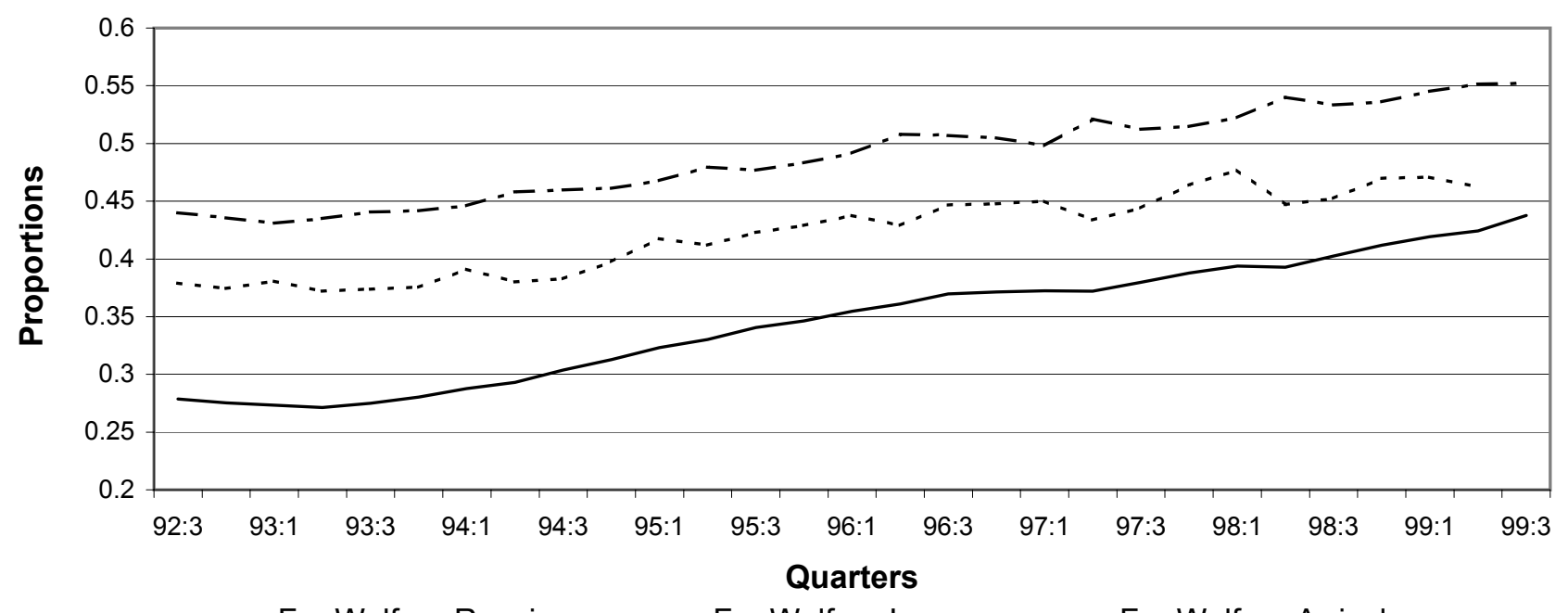

For Welfare Receivers - . - . For Welfare Leavers - - - - For Welfare Arrivals 
Figure A-7: Employment and Recidivism for the Two Cohorts
A. Percentage of Leavers Back on Welfare in Each of the Following Eight
Quarters

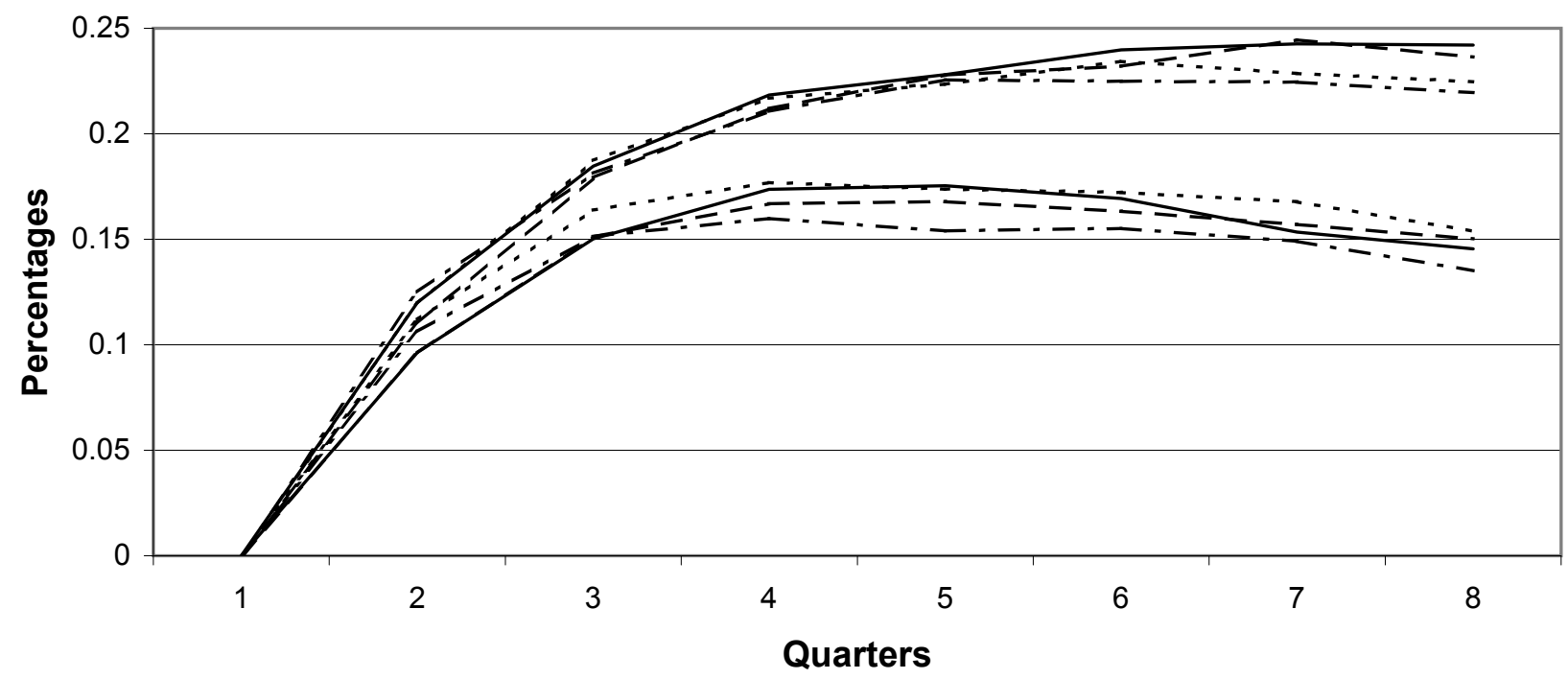

B. Employment Rate of the Leavers in the Following Eight Quarters

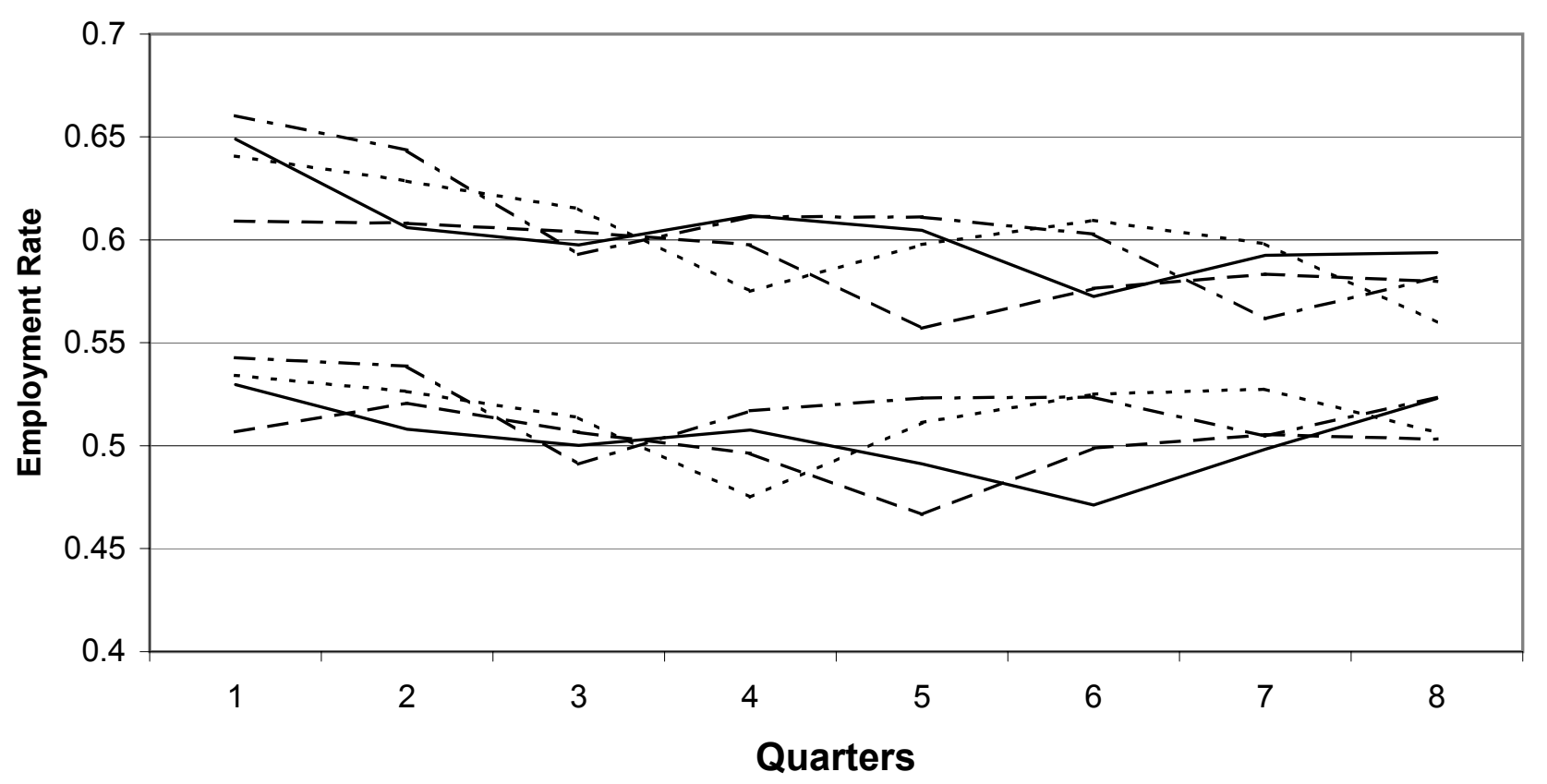

-For Leavers of 92:3 - - - For Leavers of 92:4 - . - . For Leavers of 93:1 — - - For Leavers of 93:2 -For Leavers of 96:3 — - - For Leavers of 96:4 - . - . For Leavers of 97:1 — - - - For Leavers of 97:2 
Figure A-8: Mean Earnings (adjusted to 99:2) of the Leavers in Each of the Following Eight Quarters For the Two Cohorts

A. Including Zeroes

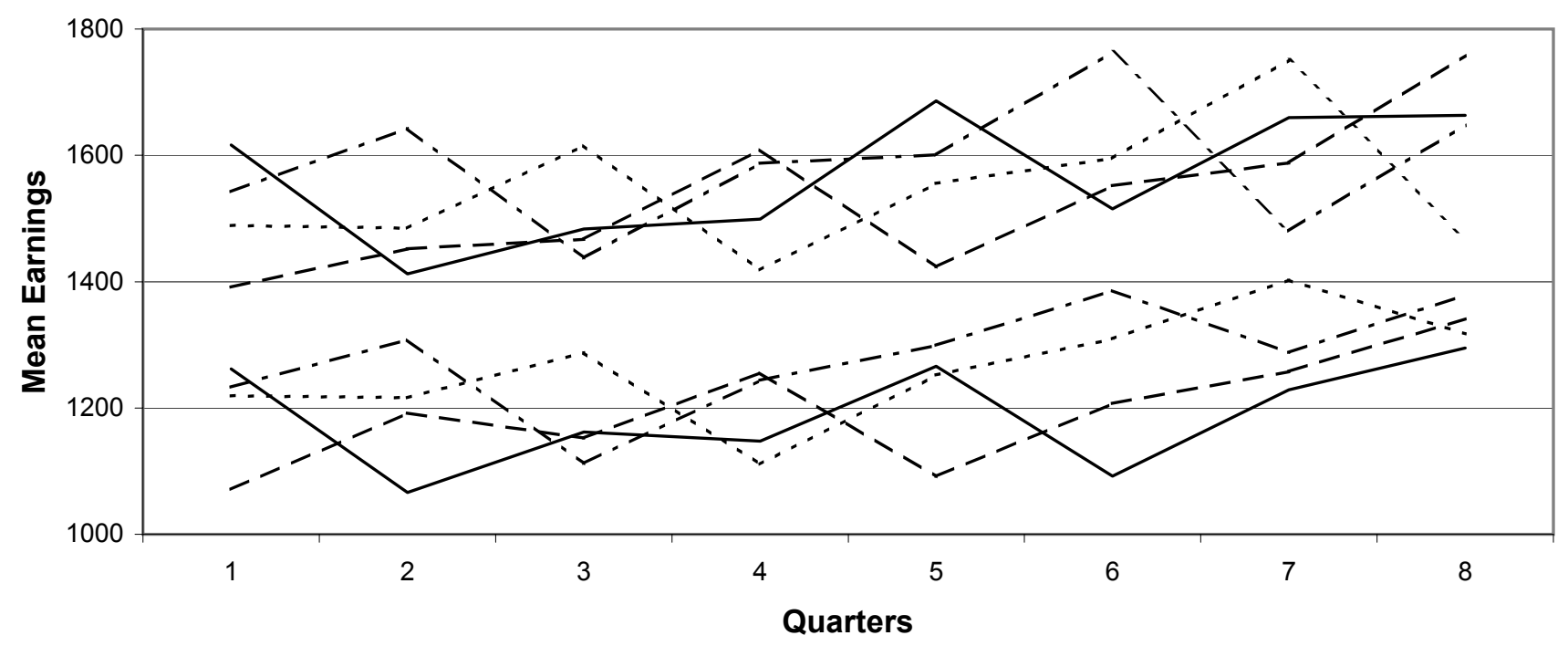

B. Excluding Zeroes

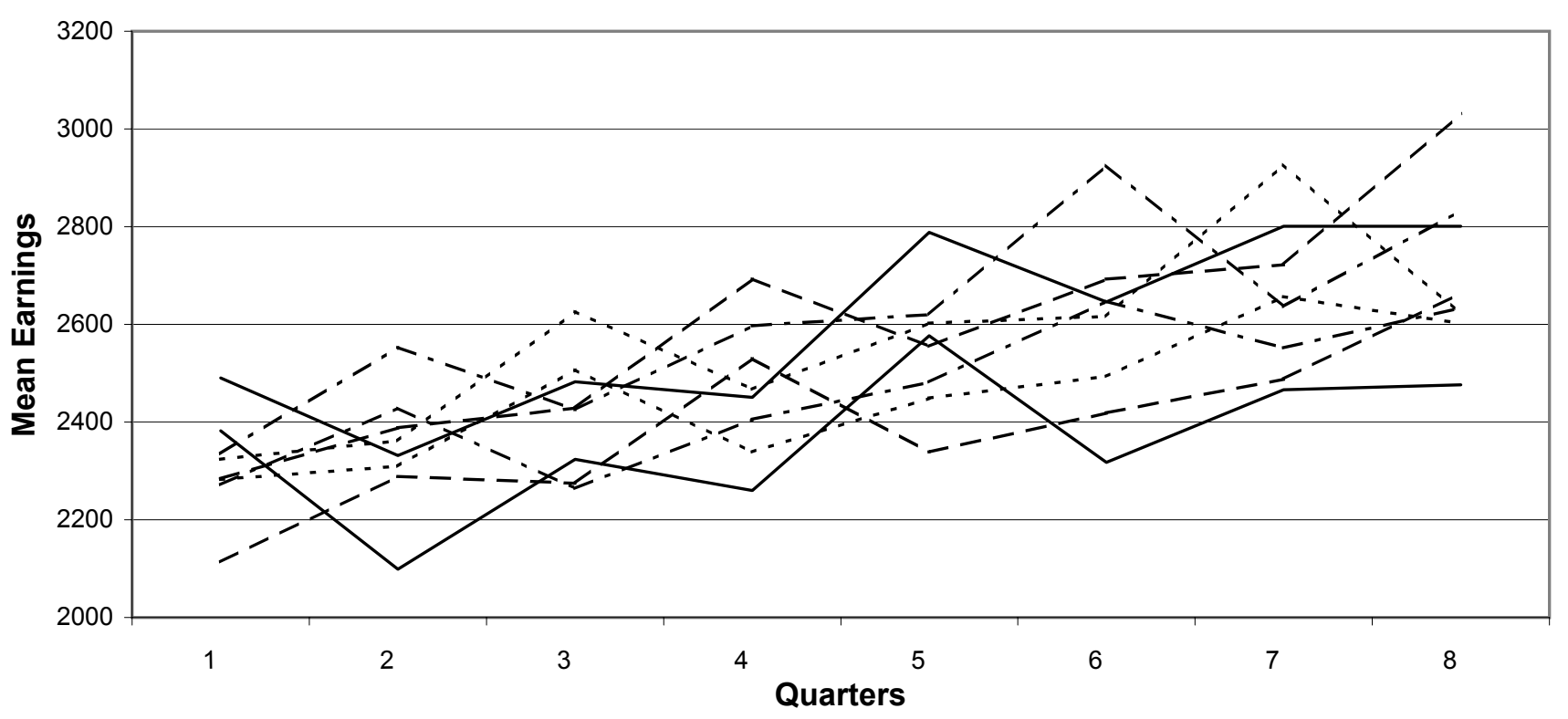

-For Leavers of 92:3 - - - For Leavers of 92:4 - . - . F For Leavers of 93:1 — - - For Leavers of 93:2

For Leavers of 96:3 — - - For Leavers of 96:4 - . - . For Leavers of 97:1 — - - For Leavers of 97:2 